

\section{DISCLAIMER}

This report was prepared as an account of work sponsored by an agency of the United States Government. Neither the United States Government nor any agency Thereot, nor any of their employees, makes any warranty, express or implied, or assumes any legal liability or responsibility for the accuracy, completeness, or usefulness of any information, apparatus, product, or process disclosed, or represents that its use would not infringe privately owned rights. Reference herein to any specific commercial product, process, or service by trade name, trademark, manufacturer, or otherwise does not necessarily constitute or imply its endorsement, recommendation, or favoring by the United States Government or any agency thereof. The views and opinions of authors expressed herein do not necessarlly state or reflect those of the United States Government or any agency thereof. 


\section{DISCLAIMER}

Portions of this document may be illegible in electronic image products. Images are produced from the best available original document. 
NOTICE

This report was prepared to document work sponsored by the United States Government. Neither the united States nor its agent, the United states Department of Energy, nor any Federal employees, nor any of their contractors, subcontractors or their employees, makes any warranty, express or implied, or assumes any legal liability or responsibility for the accuracy, completeness, or usefulness of any information, apparatus, product or process disclosed, or represents that its use would not infringe privately owned rights. 


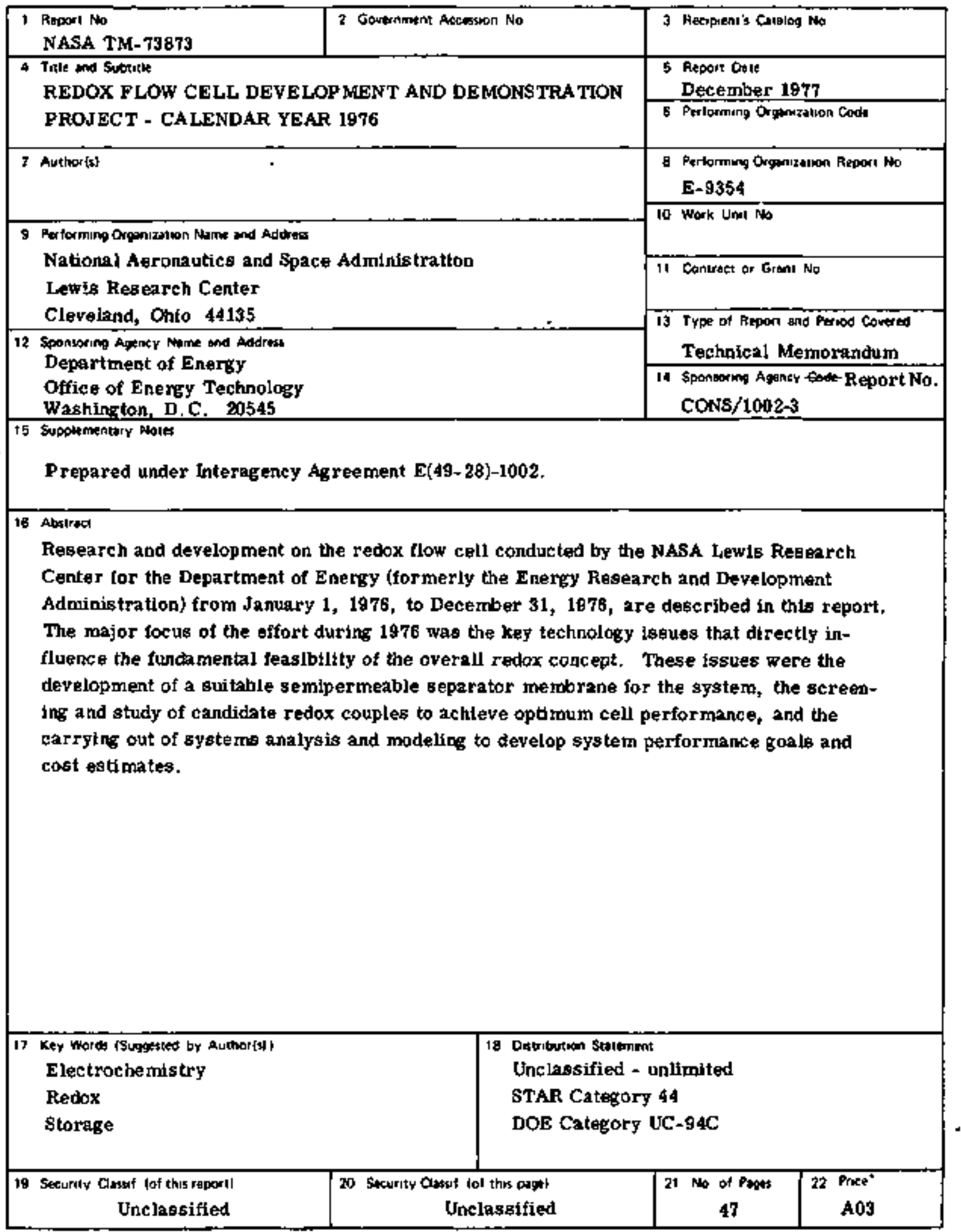

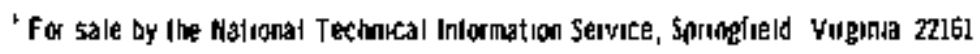


EXECUTIVE SUMMARY $\ldots \ldots \ldots \ldots \ldots \ldots \ldots$

L PROGRAM OVERVIE $\ldots \ldots \ldots \ldots \ldots \ldots \ldots \ldots$

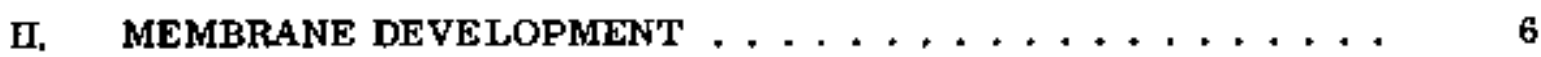

Contract Membrane Development . . . . . . . . . . . 7

In-house Membrane Development . . . . . . . . . . . 8

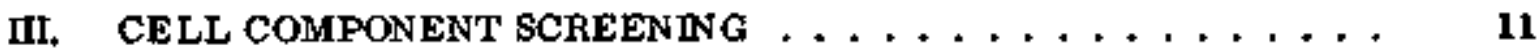

Redox Couples . . . . . . . . . . . . . . . . 13

Electrode Materials . . . . . . . . . . . . . . 17

Redox Cell Configurations . . . . . . . . . . . . 19

Electrolyte (Reactant) Solutions . . . . . . . . . . . 21

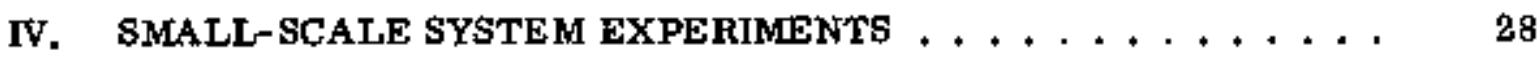

Multicell stacks . . . . . . . . . . . . . . . . 28

Redox Storage for Solar Photovoltaic Array . . . . . . . . 30

v. sYsTEM STUDIES . .................. 33

VL HYDRODYNAMICS ................... 38

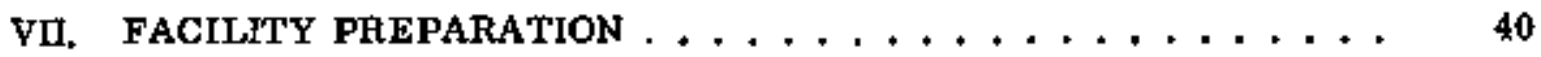

REFERENCES $\ldots \ldots \ldots \ldots \ldots \ldots \ldots \ldots \ldots$

BIBLIOGRAPHY $\ldots \ldots \ldots \ldots \ldots \ldots \ldots \ldots \ldots$

\begin{tabular}{|c|}
\hline 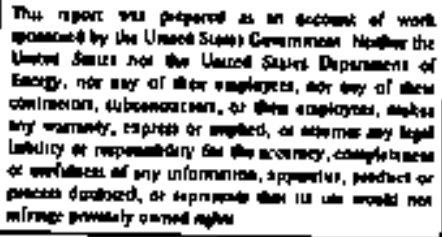 \\
\hline
\end{tabular}

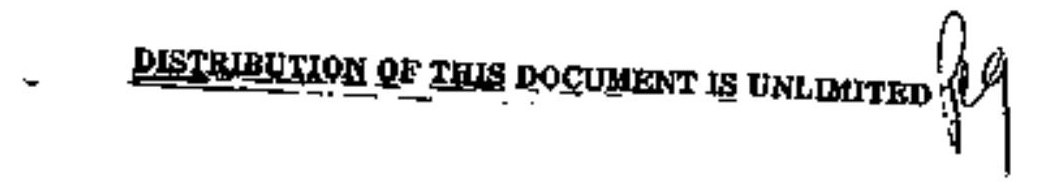




\title{
REDOX FLOW CELL DEVELOPMENT AND DEMONSTRATION PROJECT
}

\author{
Calendar Year $\mathbf{9 7 6}$ \\ EXECUTIVE SUMMARY
}

The NASA Lewis Research Center is conducting research and development for the Department of Energy (formerly the Energy Research and Development Administration), Division of Energy Storage Systems, under NASA-ERDA Interagency Agreement E (49-28)-1002, entitled "Redox Flow Cell Development and Demonstration Project." Those efforts for the period January 1, 1976, to December 31, 1976, are described in this report. The goal of this project is to develop the redox system into a viable candidate for the bulk storage of electric energy. Because of its design flexibility, in which storage capacity and power level can be sized independently, the redox system should be especially suited for operation on a weekly energy storage cycle in a utility environment. Compared to a daily storage cycle, where conventional batteries would seem to have their greatest usefulness, a weekly storage cycle can permit 150 percent more of a utility's peak energy requirement to be supported and provides a 40 percent greater discharge power capability .

The major focus of the effort during 1976 has been to address the key technology issues that directly influence the fundamental feasibility of the overall redox concept. These issues are the development of a suitable semipermeable separator membrane for the system, the screening and study of candidate redox couples to achleve optimum cell performance, and the carrying out of systems analysis and modeling to develop system performance goals and cost estimates.

Significant improvenents have been made in the semipermeable membrane in regard to the magnitude and stability of its electrical resistance and its ability to inhibit crossmixing of reactants. The following table displays the progress made in several key characteristics of membranes for the redox application. The 
ultimate goals listed for these characteristics represent ideal levels, but successful system operation can be anticipated with more modest achievements .

\begin{tabular}{|l|r|r|c|}
\hline \multicolumn{1}{|c|}{ Characteristic } & 1974 & 1976 & Ultimate goal \\
\hline Membrane life, hr & $<24$ & $>8000$ & 40000 to 80000 \\
Cell half-life (cross & 150 & 3000 & 40000 to 80000 \\
diffusion parameter), hr & & & \\
Membrane resistivity, $\mathrm{Q-cm}$ & 200 & 50 & 10 \\
Resistance stability, hr & $<1$ & 1000 & 40000 to 80 000 \\
\hline
\end{tabular}

Most of the redox couple work to date has been performed with the aqueous iron and titanium chloride redox couples as the positive and negative electrode reactants, respectively. The iron couple has shown itself to be an excellent, well-behaved electrode material. On the other hand, the titanium couple showa 1 a considerable loss of performance during the first several charge-discharge cycles. Chemical analysis of the reactant solutions has shown' that this per- : formance loss results from equilibration of the initial $\mathrm{HCl}$ supporting electrolyte . concentration gradient across the membrane and, to a much smallei extent; from the-oxidation of titanous ions by dissolved air. In view of this, a better negative electrode couple must be developed. A contract effort for the study of other redox couples yielded three potentially attractive choices for further study in 1977: $\mathrm{Cr}^{+2} / \mathrm{Cr}^{+3} ; \mathrm{Br}^{-} / \mathrm{Br}_{3}^{-}$; and $\mathrm{Cu}\left(\mathrm{NH}_{3}\right)_{2}^{+1} / \mathrm{Cu}\left(\mathrm{NH}_{3}\right)_{4}^{+2}$

Experimental evaluation of the effect of cell configuration, electrode type, : and the reactant flow hydrodynamics on cell performance has underlined the : importance of avoiding the laminar flow regime for cell reactants. Turbulence promotèrs and flowthrough'electródes, as well as inigh reactant concentrations, have been shown to greatly improve cell performance. One cell configuration, referred to as the "three stream" cell, was originally developed as a tool for 
analyzing cell performance. Clearly, it also offers an alternative approach to the design of a redox system, in the event that an adequately selective membrane is not developed. In the three-stream cell the two reactant solutions are separated by two membranes between which flows a solution of the supporting electrolyte. Reactant ions diffusing into this solution would be swept from the cell and would be recovered for reuse.

Several mathematical models of the redox system have been developed for examining the effect on system cost of variations in system and cell parameters. Use of the simplest of these models suggests that the parameters having a significant effect on systein cost are those that affect the energy density (Wh/liter) of the reactant solutions (e.g., concentration and reversible voltage). More complex models have also been applied, but subsequent analyses of these models reveal that excessively high system costs have been generated because of errors in component cost subroutines and other defects. System analysis work will continue to refine these models and to obtain more reliable system cost estimates.

\section{PROGRAM OVERVIEW}

The calendar year 1976 research and development efforts assogiated with the Redox Flow Cell Development and Demonstration Project are described. The project is being conducted by the NASA Lewis Researoh Center under Interagency Agreement E(49-28)-1002 with the Department of Energy (DOE). The project is part of the Electrochemical Energy Storage Program directed by the Division of Energy Storage Systems of DOE.

The long-term objective of this project is to develop and demonstrate a redox flow system of sufficient energy capacity to provide useful operating experience and preliminary cost data as basic input for the design and construction of large commercial systems. For the near term, attention is belng focused upon the key technology issues that will determine the fundamental feasibility of the overall redox concept.

In the final analysis, storage for electric utillties will be accepted or rejected on the basis of its impact on the economics of operation of the utilities. A viable storage system will permit the utilities to increase the load factors for their moreefficienct baseload generating equipment, and will reduce the demand on, older, 
less-efficient equipment and peaking turbines. Storage capability will also permit the utilities to increase their baseload capacities to optimum levels and to phase out, or refrain from purchasing, less-efficient equfpment.

In a study performed for DOE by the Public Service Electric and Gas Company (ref, 1), load characteristics of $199 \mathrm{U} . \mathrm{S}$. electric utility systems were analyzed. These systems represent 90 percent of the total installed capacity and 95 percent of the net energy generated in the United States. From these 199 systems, 8 were selected as being most representative of the utllity industry, based on system size, peaking season, annual load factor, daily load shape, generation mix, and geographic location. For each of these 8 representative systems an optimum baseload capacity was identified which would provide the maximum amount of off-peak (storable) energy for meeting peak requirements. The analysis reveals that the theoretical maximum amount of peak energy which could be supported by off-peak storage is about 10 percent of the annual energy production. For the study year of 1971 , this would amount to $160 \times 10^{9} \mathrm{kWh}$. On a practical level, assuming a weekly storage cycle and 75-percent electric-toelectric conversion efficiency and disregarding the off-peak energy which does not occur on a consistent basis during the entire year, the amount of supportable peak energy becomes 5 percent of annual energy generation, or $80 \times 10^{9} \mathrm{kWh}$ natlonally. Similarly, the discharge power capacity for energy storage on a typical system theoretically is $\mathbf{2 0}$ percent of the annual system peak power. For 75-percent conversion efficiency and a weekly cycle this discharge power capacity becomes 17 percent of the annual peak. When consideration is given to daily cycle operation under previously defined practical conditions, the amount of supportable peak energy falls from 5 percent to 2 percent of annusal production. and the discharge power capacity falls from 17 percent to 12 percent of the annual peak. Because the energy storage section and the power generating section of a redox system can be independently sized, such a system is more amenable than conventional batteries, to being cost-efficiently designed for a weekly duty cycle. Thus, a redox system can be more cheaply adapted to take advantage of the higher energy and power possibilties for the weekly cycle.

Solar and wind turbine generation of electric energy, because of their intermittent output will require storage capability. However, the economics of integrating storage devices into these systems is not as well defined as for utilities. 
It may be that necessity will allow a premium to be paid for storage devices with these energy systems.

Among the various technologies contending for an electric enery storage role, one of the more attractive is electrochemical storage. Of course, no battery system of the size necessary for utility applications ever has been assembled. Present batteries, having well-developed technologies, may be troubled by cost, depth-of-discharge limitations, electrode morphology changes, and cycle-life limitations. Economic evaluation of advanced batteries is made difficult by the rudimentary state of the art .

Redox systems are not batteries in the traditionsl sense. Although some electrochemical technology is common to both, the redox system has a much: greater similarity to fuel cell systems. The redox system being developed at Lew is is referred to as a "two tank" system because each reactant is continuously recirculated between its respective storage tank and the power-generating module. The higher-than-stoichiometric flow rates enhance mass transport at the redox cell electrodes. Also, the fact that the reactants are only fractionally depleted on each pass through the cells permits higher power densities than can be achieved with single-pass (four tank) systems. Because there is no phase change as a recox couple is charged or discharged, there are no inherent depth-of-discharge or cycle-life limitations for a redox systen. Materials problems are minimized because operating temperatures are mild. An additional advantage over conventional batteries is that the energy storage capacity and the power generation capability of a redox system can be independently sized, permitting optimum reectant utilization and cost efficient design for weekly cycle operation. Also the modular character of redox system components will permit efficient expansion. to meet evolving power levels and load factors.

In theory, the major drawback to a redox, system is that, because of the modest energy density of its reactent solutions, it is a high-volume system. This will be reflected in costs for land and tankage. In practice, the problems encountered at Lewis revolve around the development of a suitable membrane and an adequate negative reactant/electrolyte/electrode combination for the redox system. Most of the redox project effort during 1976 has been directed toward these problems. 
In the membrane area, development and evaluation were pursued in-house and under contract with lonics, Inc. Both efforts have resulted in considerable improvenents in membrane resistance stability and the ability to prevent crossmixing of reactant ions. Screening of redox couples at Giner, Ine., has . resulted in the selection of three potentially attractive couples which will be evaluated in depth during 1977. Work at Giner, Inc.., and in-house has given insight into the interrelationship of electrode type, cell configuration, and reactant flow hydrodynamics in regard to cell performance. Extensive study of the iron-titanium couple pair has shown the iron couple to be an admirable positive material and has resulted in an understending of the problems associated with the negative titanium couple. A three-stream cell configuration has been developed. It is a useful analytic tool and also offers an alternative system design approach if adequately selective membranes cannotbe developed. Mathematical models of the redox system are being developed to determine the effect on system cost of variations in cell operating parameters.

It is anticipated that the continuation of these efforts during 1977 will go a long way toward showing that the redox storage system concept is an attractive technology for electric utilities.

\section{MEMBRANE DEVELOPMENT}

Investigation early in the Redox Flow Cell Development and Demonstration Project revealed that no commercially available anion-exchange membranes . could meet the requirements of the Lewis redox cell. These requirements include low resistivity, high ion-exchange capacity for the restriction of metalion transport, stability in the redox cell environment, and ease of manufacture and handling. Parallel efforts are being carried out in-house and under contract to develop new membranes or to modify existing ones to meet these requirements. The membranes being studied under contract are homogeneous films of copolymerized or crosslinked fon-exchange monomers on a fabric support. The in-house membranes are heterogeneous mixtures of Kraton (B) rubber, materials with amine functional groups, and, in some cases, inert fllers. These mixtures are coated onto an asbestos substrate or extrucied as films : 


\section{Contract Membrane Development}

The current membrane development program at lonics, Inc., began in July 1976 and is a follow-on to the contract effort by that company in 1974-75. Three major tasks are included in this program:

(1) Synthesize and screen new or unproven membranes (eight in all) for the redox cell application. Screening parameters are ion-exchange capacity, water content, resistance, and ferric ion permeation rates.

(2) Optimize the six most promisting candidate membranes (three identified in the initial program and three from the preceding task). Optimization is directed toward increasing selectivity for cation transfer, minimizing resistivity, and enhancing durability in the redox cell environment. Vartations in solvent content, water content, crosslink type, and crosslink density are being evaluated.

(3) Scale-up membrane fabrication for the optimized systems to demonstrate production capabilities, and-a detailed characterization of electrical and physical properties.

During 1976, three of the eight Task 1 materials were prepared and tested. Preliminary results were as follows:

(1) System CDIL (vinylbenzylchloride crosslinked with dimethylaminoethylmethacrylate on a cloth support): This is a "self-crosslinking" resin which shows good durability and very good selectivity for exclusion of $\mathrm{Fe}^{\mathbf{t n}}$. Initial problems with pin-hole formation during preparation appear to have been overcome, and this system is a prime prospect for continued study. It exhibits exceptional selectivity, conductivity, and durability in the redox environment.

(2) System VC (commercial vinylchloride film aminated with tetraethylenepentamine): The tough, flexible nature of these unsupported membranes is most desirable. However, to date they have not consistently shown adequate selectivity and conductivity.

(3) System CE (vinylbenzylchloride crosslinked with ethylenediamine on a cloth support): This "self-crosslinking" system offers excellent potential for high ion-exchange capacity (desirable for both good ion exclusion and con- 
ductivity). How ever, to date, useful membrane samples have not been reproducibly obtained.

The three most'promising membranes from the first contract program were studied to determine compositions and procedures for fabrication of membranes. having optimal selectivity and conductivity in the redox environment. The current status of these systems is

(1) System 103QZL (vinylbenzylchloride crosslinked with divinylbenzene and aminated with trimethylamine on a cloth support): This is an improved version of a commercially avallable membrane whiah has performed quite well in the redox environment. Recent formulations of this membrane system have shown significant reductions in the transport of cations in the test environment.

(2) System B2L (vinylbenzylchloride crosslinked with divinylbenzene and aminated with diethylenetriamine on a cloth support): The ethylenegiycoldimethacrylate crosslinks of the original formulation were replaced to improve erosion resistance of the resin. However, the current formulation does not show adequate durability in the redox environment and appears to lose both selectivity and conductivity during use.

(3) System A3L (2-vinylpyridine crosslinked with divinylbenzene on a cloth support): This system exhibits good electrical and physical properties and appears very desirable for acidic solutions. Cracks sometimes appear in large samples, however; and variations in its preparation have been considered to circumvent this problem.

Data for the latter three systems, plus the CDlL membrane, are shown in table 1 . The effect of membrane water content on ferric ion selectivity is significant.

\section{In-house Membrane Development}

The prototype heterogeneous membrane formulation developed at Lewir consists of Kraton $(\$)$ rubber, crosslinked vinylpyridine, and magneslum zirconium silicate filler. This formulation, designated as DS-156, is generally coated onto an asbestos substrate but also has been extruded as a film. Variations of this formulation. plus samples of the homogeneous membranes developed at Ionics, Ine., have been evaluated in operating redox cells. The conflguration 
TABLE 1. - PHYSICAL PROFERTIES OF SELECTED IOHICS, INC., MEMBRANES

\begin{tabular}{|c|c|c|c|c|c|}
\hline \multirow[t]{2}{*}{ Membrane } & \multirow{2}{*}{$\begin{array}{l}\text { Ion exchange } \\
\text { capacity, } \\
\text { milliequivalenta } \\
\text { per dry gram }\end{array}$} & \multirow{2}{*}{$\begin{array}{l}\text { Water } \\
\text { content, } \\
\text { percent }\end{array}$} & \multicolumn{2}{|c|}{$\begin{array}{c}\text { Resistance, } \\
n-\mathrm{cm}^{2}\end{array}$} & \multirow{2}{*}{$\begin{array}{l}\text { Iron ion } \\
\text { transport } \\
\text { rate, } \\
\mathrm{P}_{\mathrm{Fe}}^{+} \\
\text {mg } \mathrm{Fe} / \mathrm{m}\end{array}$} \\
\hline & & & $a_{R_{\zeta}}^{C}$ & $\mathrm{~b}_{\mathrm{B}_{\zeta}^{\mathrm{J}}}^{\mathrm{J}}$ & \\
\hline $\begin{array}{c}\text { 103Q2L: } \\
\text { New } \\
\text { Old }\end{array}$ & $\begin{array}{l}2.24 \\
2.34\end{array}$ & $\begin{array}{l}25,4 \\
36,6\end{array}$ & $\begin{array}{r}10.6 \\
9.5\end{array}$ & $\begin{array}{l}7.2 \\
4.1\end{array}$ & $\begin{array}{c}2 \text { to } 3 \\
1000 \text { to } 3200\end{array}$ \\
\hline $\begin{array}{l}\text { B2L: } \\
\text { INew } \\
\text { Old }\end{array}$ & $\begin{array}{l}3.53 \\
5.38\end{array}$ & $\begin{array}{l}27.7 \\
41.9\end{array}$ & $\begin{array}{l}8.7 \\
8.0\end{array}$ & 10.1 & $\begin{array}{l}1 \text { to } 2 \\
30\end{array}$ \\
\hline $\begin{array}{l}\text { A3L } \\
\text { New } \\
\text { Old }\end{array}$ & $\begin{array}{l}3.10 \\
3.12\end{array}$ & $\begin{array}{l}31.6 \\
39.8\end{array}$ & 9.1 & 9.6 & 1 to 2 \\
\hline $\begin{array}{l}\text { CDI } \\
\text { Hew } \\
\text { old }\end{array}$ & $\begin{array}{l}3.91 \\
4.05\end{array}$ & $\begin{array}{l}31.3 \\
41.8\end{array}$ & $\begin{array}{l}6.9^{1} \\
4.9\end{array}$ & $\cdots$ & $\begin{array}{r}2 \\
50\end{array}$ \\
\hline
\end{tabular}

ENeasured by contact probes in $0.1 \mathrm{~N} \mathrm{HCl}$ at $25^{\circ} \mathrm{C}$,

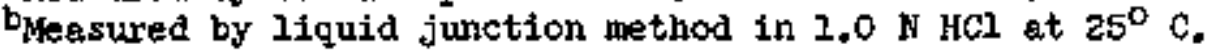

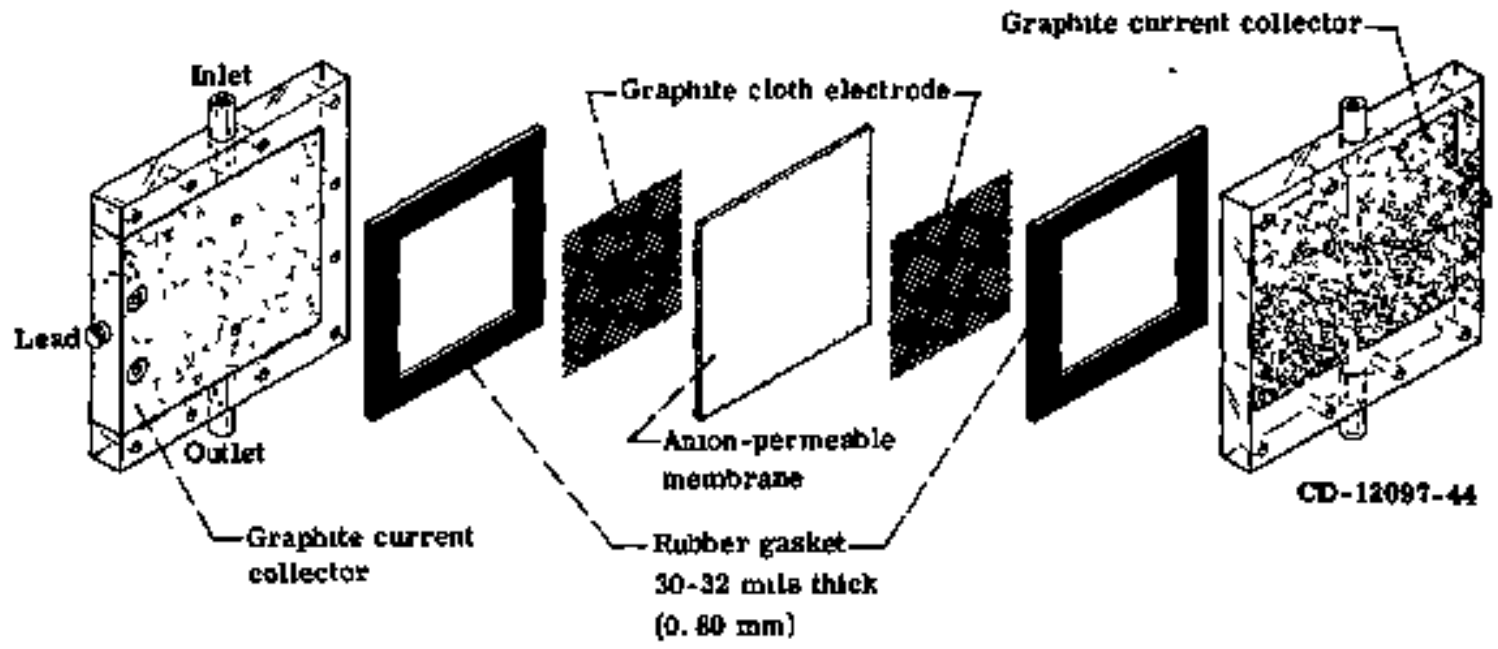

Fyoure 1. - Conisguratum of laboratory redox cell. 
of these cells, shown in figure 1 , consists of graphite cloth electrodes sandwiched between the test membrane and the respective graphite foil current collectors. The ective cell area is $14.5 \mathrm{~cm}^{2}$. In most cases the redox solutions used have been $1 \mathrm{M} \mathrm{FeCl}_{3}(0.5 \mathrm{~N} \mathrm{HCl})$ and $1 \mathrm{M} \mathrm{TiCl}_{3}(6.0 \mathrm{~N} \mathrm{HCl})$. Testing has consisted of repetitive charge-discharge cycles.

The primary sriteria for evaluating the membranes have been resistance, resistance stability, and the "iron transport half-life" of the cell. This later term is defined as the extrapolated time required for one-half of the Iron ions originally present to cross the membrane into the titanium half-cell. This "time" is fictitious, in that infinite time would be required for the iron concentration to become equal on both sides of a membrane. It serves well, how ever, as a screening parameter. Cell resistance was perladically measured with an alternating-current bridge at $1000 \mathrm{~Hz}$. Spectrophotometric analysis of periodically taken samples of the respective reactant solutions established the cell halt-life. In addition, chemical analyses were made to determine trangference numbers, charging efficiencies, and the nature of possible gide reactions.' The concentrations of reduced metal ions in the sample were measured by potentiometric titration with $\mathrm{KMnO}_{4}$, using a platinum indicator electrode and a silver silver chloride reference electrode. The cutoff potentials are $+300 \mathrm{mV}$ for $\mathrm{Ti}^{+3}$ and $+700 \mathrm{mV}$ for $\mathrm{Fe}^{+2}$. The oxidized specles concentrations were then determined by difference after completely reducing the sample in a Jones reductor and repeating the titration. Chloride ion concentration was measured by a potentiometric titration with $\mathrm{AgNO}_{3}$, and hydrogen ion concentration was calculated from charge-balance considerations.

Some general conclusions can be drawn from the chemical analyses performed (ref, 2 ):

(1) A greater portion of cell current is adried by protons than by chloride ions, even though the membranes are designed to be anion exchangers.

(2) Titanium diffusion rates through the membranes are roughly equivalent to those of iron.

(3) Equilibration of acid concentrations occurs quite rapidly when the half-cell acidities initially differ. 
The results from the evaluation of six membranes produced during the initial contract with Ionics, Inc., are presented in table 2. The projected half-lives range from about 400 hours to about 2000 hours. The resistances are quite stable for as long as 1 month of testing. Judging from the reduction in iron permeability achieved by lonics, Inc., for improved versions of three of these membranes (table 1), it is expected that in-house evaluation of these three will show much greater projected half-lives than those given in table 2 .

A handmade baseline in-house membrane (DS-156) was compared with a membrane of the same formulation produced on a continuous slurry-coating machine (DS-156D), The machine-coated material apparently has a much tighter structure because its iron-transport half-life was 2900 hours as compared with 600 hours for the handmade sample. Also, the resistance for DS$156 \mathrm{D}$ was $1.0 \mathrm{ohm}$, as compared with $0.6 \mathrm{ohm}$ for DS-156.

Other handmade membranes consisting of an asbestos substrate coated on one side with a tertiary anine-bearing material (vinylpyridine) and on the ather side with a quaternary amine-bearing material (IRA-400) have been tested. The data in table 3 show a significant improvement in iron transport half-life when the tertiary amine faces the iron solution. The first two membranes in the table differ only in their orientation in the test cell. The first pair of membranes differs from the second pair in that the latter contains magnesium zirconium silicate tiller. The K9098R membrane is especially attractive because of its low and stable resistance. It is expected that machine production of these membranes would result in even greater half-lives. Work is continuing in this area.

The baseline heterogeneous formulation was successfully extruded as a film (as opposed to being coated on an asbestos substrate). However, initial runs produced overly porous membranes, Reduction of the ionic-material content of the formulation should alleviate this problem.

\section{CELL COMPONENT SCREENING}

In parallel with the development of membranes suitable for the redox cell, it is necessary to evaluate the effect that other factors have on cell performance. These include the redox couple pair, the supporting electrolyte, the electrode 
TAELE 2. - IRON TRAHEFORT HALF-EIFE AND RESISTANGE FO' IONICS, IFC, , MEMERANES

\begin{tabular}{|c|c|c|c|c|}
\hline Membrane & $\begin{array}{c}\text { Projectod } \\
\text { iron } \\
\text { half-life, } \\
\text { hr }\end{array}$ & $\begin{array}{c}\text { Resis- } \\
\text { tir- } \\
\text { ity } \\
\text { itcon }\end{array}$ & $\begin{array}{c}\text { Initial } \\
\text { resistence, } \\
n\end{array}$ & $\begin{array}{l}\text { Resiatance } \\
\text { change, } \\
\text { M/day }\end{array}$ \\
\hline $\begin{array}{l}A 3 L-2 B A \\
A 3 \pi-29 A^{a}\end{array}$ & $\begin{array}{l}780 \\
795\end{array}$ & 134 & 0.47 & 0.0055 \\
\hline B2L-DI34A & 1030 & 171 & .60 & .0005 \\
\hline $\begin{array}{l}A 4 L-28 A_{a} \\
A 4 L-28 A^{2}\end{array}$ & $\begin{array}{l}2050 \\
1550\end{array}$ & $\begin{array}{l}126 \\
126\end{array}$ & .44 & $\begin{array}{l}.0025 \\
.0025\end{array}$ \\
\hline $\begin{array}{l}\text { VCI-TP-12X } \\
\text { VCI-TP-12X }\end{array}$ & $\begin{array}{l}370 \\
470\end{array}$ & $\begin{array}{r}91 \\
127\end{array}$ & $\begin{array}{l}.32 \\
.41\end{array}$ & $\begin{array}{l}-.0008 \\
-.0058\end{array}$ \\
\hline B2L-DT95 & 1365 & 171 & .60 & -.0029 \\
\hline $\begin{array}{l}Q 2 \pi-219 \\
Q Z L=219^{2}\end{array}$ & $\begin{array}{r}905 \\
2770\end{array}$ & $\begin{array}{l}145 \\
160\end{array}$ & .50 & $\begin{array}{l}.0061 \\
.0107\end{array}$ \\
\hline
\end{tabular}

Duplicate test.

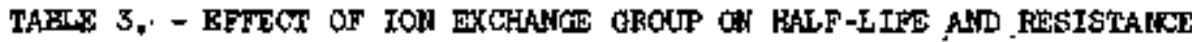

\begin{tabular}{|c|c|c|c|c|c|}
\hline Membrane & $\begin{array}{l}\text { Orientation: } \\
\text { tertiary amine } \\
\text { facing titanive } \\
\text { or iron solution }\end{array}$ & $\begin{array}{c}\text { Projected iron } \\
\text { half-life, } \\
\text { hr }\end{array}$ & $\begin{array}{c}\text { Fossistivity, } \\
0-c h \\
-\end{array}$ & $\begin{array}{c}\text { Init1al } \\
\text { resistance, } \\
\Omega\end{array}$ & $\begin{array}{l}\text { Resistanice } \\
\text { change, } \\
\text { n/day }\end{array}$ \\
\hline K717 AR & $T 1$ & 2100 & 323 & 1.13 & 0.044 \\
\hline KJITIR & - $\mathbf{P e}$ & 5600 & 328 & 1.15 & $\therefore .018$ \\
\hline K990月 & $T i$ & 3500 & 482 & -1.48 & .028 \\
\hline & $\mathrm{Fe}$ & & 231 & .81 &., 005 \\
\hline
\end{tabular}


materials, and the overall cell configuration. Most of the in-house effort during 1976 focused on the iron-titanium couple pair, and most of the testing was performed on the standard laboratory cells described in sextion $\mathbf{I}$ and figure 1.

\section{Redox Couples}

Among the characteristics desirable in a redox couple are a relatively high reversible potential; fast kinetics during charge and discharge; reversibility; high solubility; simple, one-step charge transfer reactions; and an absence of side-reactions with the electrodes or electrolyte. Of course, some of these characteristics (e.g., reaction kinetics) are strongly influenced by the electrode being used.

Giner, Inc., was awarded a contract to examine potentially attractive couples with regard to some of these factors. This contract was carried out in two phases: a broad investigation of the basic characteristics and behavior of various redox couples, followed by a more limited investigation of their electrochemical performance in a redox flow reactor configuration.

The primary objective of the first phase of the program was to evaluate eight redox couples under a veriety of conditions in terms of their exchange current densities as measured by the rotating-disk electrode procedure. The redox couples investigated in this first phase were $\mathrm{Fe}^{+2} / \mathrm{Fe}^{+3}, \mathrm{Ti}^{+3} / \mathrm{Ti}^{+4}$,

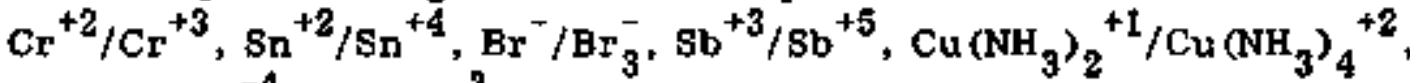
and $\mathrm{Cr}(\mathrm{CN})_{6}^{-4} / \mathrm{Cr}(\mathrm{CN})_{6}^{-3}$. Ideally, the couples were to be tested on gold and graphite electrodes at 80 and $120 \mathrm{~F}$; reduced-to-oxidized ratios of $1: 10,1: 1$, and $10: 1 ;$, and total concentrations of $1 \mathrm{M}, 3 \mathrm{M}$, and $6 \mathrm{M}$. In actual testing, solubility and corrosion effects frequenty limited the range of conditions.

The results from the first phase (table 4) showed the more-promising couples to be $\mathrm{Fe}^{+2} / \mathrm{Fe}^{+3}, \mathrm{Br}^{-} / \mathrm{Br}_{3}{ }^{-}, \mathrm{Ti}^{+3} / \mathrm{Ti}^{+4}, \mathrm{Cr}^{+2} / \mathrm{Cr}^{+3}$, and $\mathrm{Cu}\left(\mathrm{NH}_{3}\right)_{2}^{+1} /$ $\mathrm{Cu}\left(\mathrm{NH}_{3}\right)_{4}^{+2}$. The $\mathrm{Fe}^{+2} / \mathrm{Fe}^{+3}$ and $\mathrm{Br}^{-} / \mathrm{Br}_{3}^{-}$, couples were chosen as the positive electrodes in the second phase of testing for their high exchange current

*The contractor's final report (ref. 3) contains more-detailed information and should be consulted for an in-depth review and understanding of this topic . 
TABLE 4, - APFROX DMATE EFFECTIV EXCHANGE CURREINT AND

REYFRSIBLE POTENTIAL

\begin{tabular}{|c|c|c|}
\hline Couple & $\begin{array}{c}\text { Exchange current } \\
\text { density, } \\
\mathbf{i}_{\mathrm{g}}, \mathrm{m} \\
\mathrm{mA} / \mathrm{cm}^{2}\end{array}$ & $\begin{array}{l}\text { Reversible potential, } \\
\text { V (as compared with } \\
\text { saturated calonil } \\
\text { electrode). }\end{array}$ \\
\hline \multicolumn{3}{|c|}{ Anodes } \\
\hline $\mathrm{Cu}\left(\mathrm{NH}_{3}\right)_{2}^{+1} / \mathrm{Cu}\left(\mathrm{NH}_{3}\right)_{4}^{+2}$ & 20 & -0.3 \\
\hline $\mathrm{Ti}^{+3} / \mathrm{TiO}^{+2}(6 \mathrm{M} \mathrm{HCl})$ & 1 & -.1 \\
\hline $\mathrm{Cr}^{+2} / \mathrm{Cr}^{+3}(1 \mathrm{MHCl})$ & 0.1 to 1 & $\therefore .4$ \\
\hline $\mathrm{Sn}^{+2} / \mathrm{sn}^{+4}(3.5 \mathrm{M} \mathrm{HCl})$ & 0.01 to 3 & -.1 \\
\hline \multicolumn{3}{|c|}{ Cathodes } \\
\hline $\mathrm{Br} / \mathrm{Br}_{3}(\mathrm{NaBr})$ & 3 & $+0.8:$ \\
\hline $\mathrm{Fe}^{+2} / \mathrm{Fe}^{+3}(1 \mathrm{MHCl})$ & 10 & +.5 \\
\hline $\mathrm{sb}^{+3} / \mathrm{sb}^{+5}(3 \mathrm{M} \mathrm{HCl})$ & & +.6 \\
\hline
\end{tabular}


densities and reasonable solubility limits; $\mathrm{Br}^{-} / \mathrm{Br}_{3}^{-}$also has a very high open-

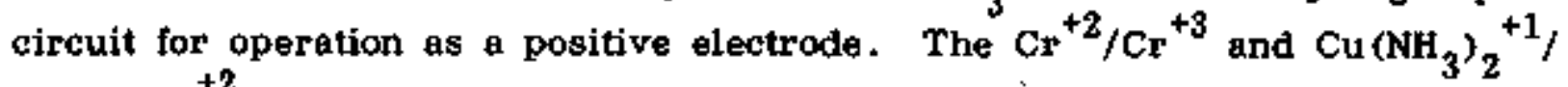
$\mathrm{Cu}\left(\mathrm{NH}_{3}\right)_{4}{ }^{+2}$ couples were chosen for study, as negative electrodes, due to their reasonably high exchange current densities. (The titanium couple, although better than the chromium couple, was not chosen in order to avoid duplication of previous extensive study at Lewis.)

The second phase of the program involved the testing of these four couples In a redox reactor under flow conditions with a variety of electrode materials and structures, The best performance with the negative electrode couples was obtained with the $\mathrm{Cu}\left(\mathrm{NH}_{3}\right)_{2}{ }^{+1} / \mathrm{Cu}\left(\mathrm{NH}_{3}\right)_{4}{ }^{+2}$ couple, particularly when a gold sereen electrode was used in a frontal structure (i.e., electrode placed against the ion exchange membrane with electrolyte flowing on the back). The best performance with the positive electrode couples was obtained with the $\mathrm{Br}^{-} / \mathrm{Br}_{3}^{-}$ couple, particularly with porous carbon electrode in a recessed structure (described in REDOX CELL CONFIGURATIONS section). The Fe $e^{+2} / \mathrm{Fe}^{+3}$ couple using a graphite woven-cloth electrode (as has been studied at Lewis) also showed very good performance. The considerable effect of electrode material, structure, and cell configuration on cell performance suggests that much attention must be given to the optimization of a cell for a given redox couple.

The kinetic behavior of the iron couple was also studied at Lewis with the rotating-disk electrode (RDE) technique (ref. 4). Edge-on pyrolytic graphite (EOPG) electrodes were used in $\mathrm{HCl}$-acidified solutions with total iron concentrations ranging from 0.2 to $3.3 \mathrm{M}$. The range of oxidized-to-reduced species concentrations was from $1: 10$ to $10: 1$.

In figure 2, polarization curves are shown for three RDE rotational speeds in the $1 \mathrm{M} \mathrm{FeCl}_{2} / 2 \mathrm{M} \mathrm{FeCl} / 0.5 \mathrm{~N} \mathrm{HCl} \mathrm{system.} \mathrm{Also} \mathrm{shown} \mathrm{is} \mathrm{the} \mathrm{Tefel} \mathrm{plot}$ derived by extrapolating these data to infinite rotational speed. This particuthr set of data reveais two distinct Tafel slopes when the electrode is polarized anodically. Extrapolation of the Tafel plots to the points of zero polarization gives exchange currents of 13.5 and $29.4 \mathrm{~mA} / \mathrm{cm}^{2}$, indicating good electrode kinetics for the iron couple. The exchange current density, when expressed as a standard rate constant $\left(\mathrm{k}_{\mathrm{s}}=i_{0} /\left[\mathrm{Fe}^{+37}\right]^{1 / 2}\left[\mathrm{Fe}^{+2}\right]^{1 / 2} \mathcal{F}\right)$, is quite insensitive to total iron ion concentration over the range of concentrations studied. This is encouraging because total system cost can be significantly reduced by increasing reactant concentration. 


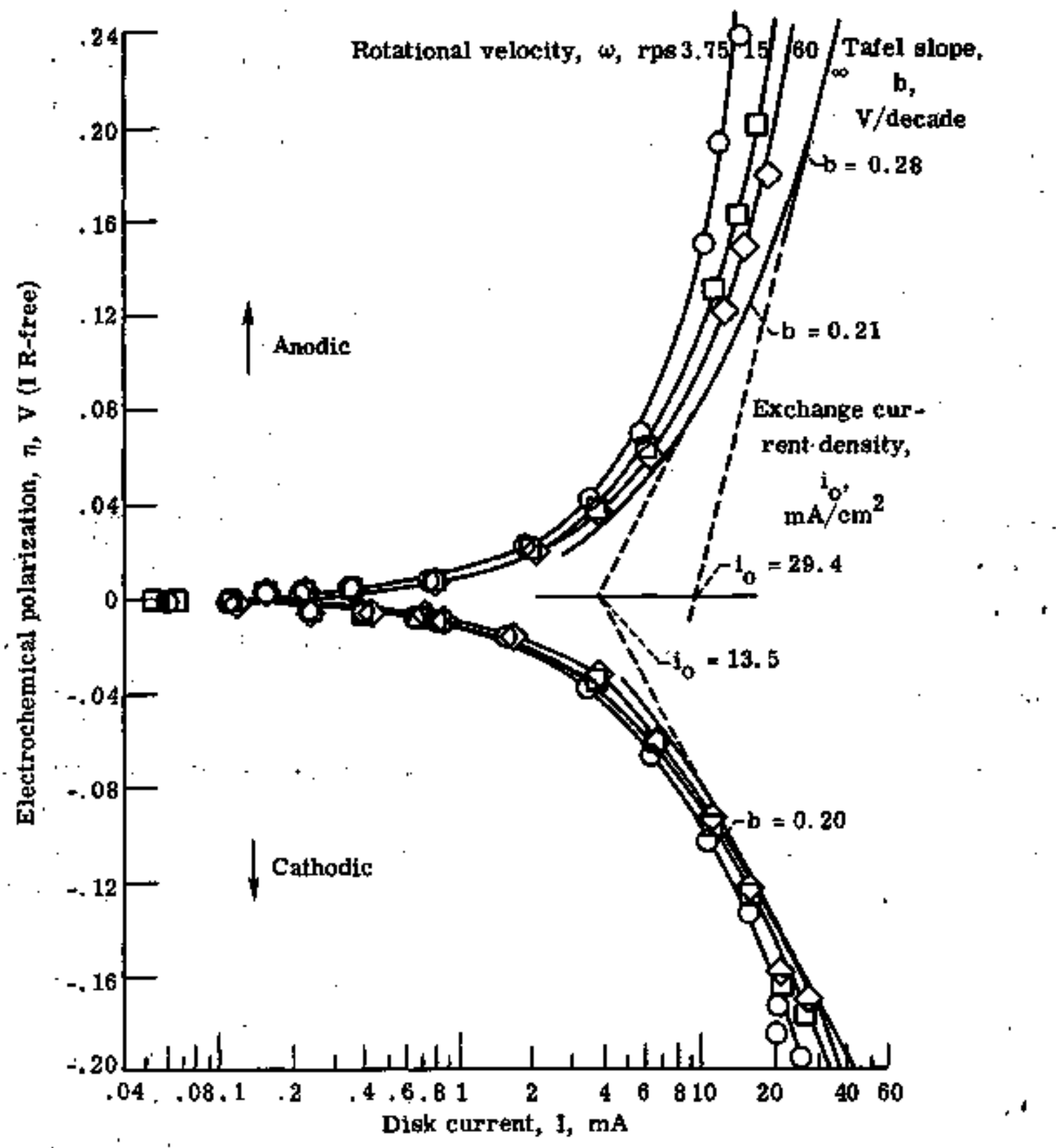

- Figure 2. - Polarization curves and Tafel plot for edge-on pyrolytic graphite (EOPG) rotating disk electrode (RDE) in the $1 \mathrm{M}$ $\mathrm{FeCl}_{2} / 2 \mathrm{M} \mathrm{FeCl}_{3} / 0.5 \mathrm{~N} \mathrm{HCl} \mathrm{system} \mathrm{(i.} \mathrm{e.,} \mathrm{exchange} \mathrm{current}$ density, $\mathrm{mA} / \mathrm{cm}^{2} ; \mathrm{b}$, Tafel slope, volts per decade; area of. disk, $0.32 \mathrm{~cm}^{2}$ ). 
Several of the redox couples examined by Giner, Inc., were paired and evaluated in laboratory cells at Lewis. Discharge curves for these couple pairs are presented in figure 3. The poor coulombic efficiency for the cells with a chromitum anode is typical for graphite cloth electrodes and probably resulte from a combination of hydrogen evolution during charge, reduction of the solvent by the chromous ion, and air-oxidation of the chromous ion.. Because of the attractive open-circuit potential for the fron-chromium pair, it will be subjected to intensive investigation during 1977. (All cells except the irontitanium cell were very difficult to charge.)

\section{Electrode Materials .}

The desirable characteristics for a redox cell electrode include high conductivity, high surface area, high gas evolution overpotential, catalytic activity during charge and discharge, and chemical stability toward the reactant solution. Because most of the in-house effort this year has focused on the iron-titanium pair, for which graphite cloth and felt are excellent electrode materials, not much screening of other electrodes has been done. However, lead plates and sinters were examined as a possibility for the chromium couple; because this metaI has a high hydrogen evolution overpotential. The lead electrode for a short while permitted chromium charging rates about twice as high as did graphite. Reaction of the lead with the acid electroly te then slowly resulted in passivation. There was no improvement over graphite in charging efficiency .

During the cell component screening program at Giner, Inc., electrode materials examined for the various redox couples included various forms of platinum, gold, titanium, carbon, graphite, and ruthenium oxide. Although results were greatly influenced by cell configuration, flow rates, and other operational factors, they show that graphite cloth, porous carbon, and gold were the best materials for the iron, bromine-bromide, and copper-ammonium complex couples, respectively. None of these materials proved to be of value for the chromium couple. 


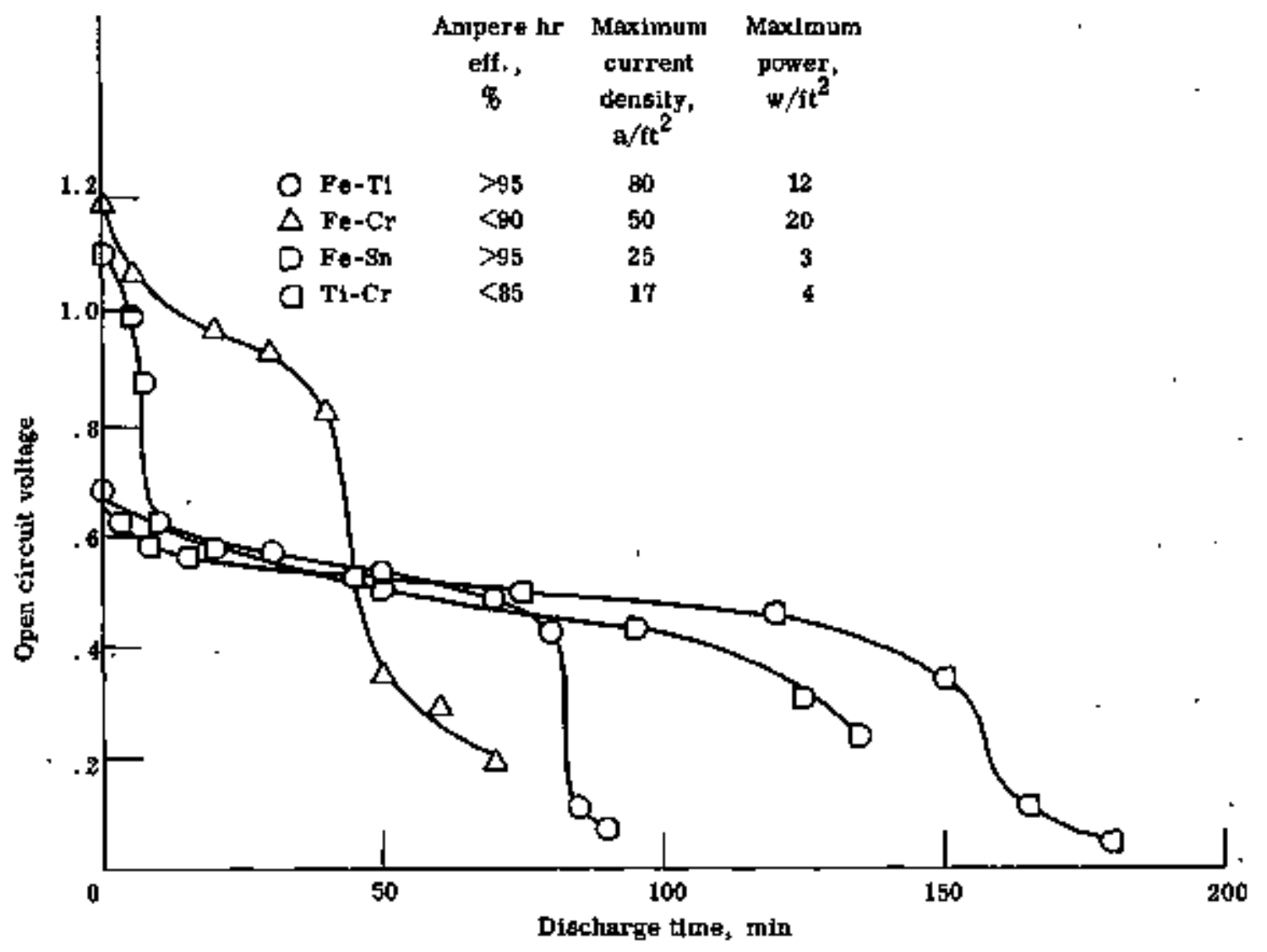

Figure s. - Open-circuit potential versus discharge tlme for selected redox couple pairg. 


\section{Redox Cell Configurations.}

In the work at Giner, Inc., it was shown that the performance of a given electrode/redox couple combination could be greatly influenced by the overall cell configuration. During the course of this study, three broad types of cell stmotures were considered:

(1) Frontal electrode structures: The electrode was a porous open structure like sereen or graphite paper. It was placed in contect with the ion exchange membrane, and the reactant-electrolyte flowed behind the electrode through a "pin" field in the back plate of the cell.

(2) Recessed electrode structures: The electrode was either a nonporous sheet like platinized titanium sheet or a microporous structure like carbon or activated carbon. It was located against the back plate of the cell with coarse plastic screen between the electrode and the ion exchange membrane, permitting reactant-electrolyte to flow in front of the electrode.

(3) Cavity filling electrode structures: A typical example of this structure used the graphite woven-cloth electrode as in the Lewis experiments. This type of electrode filled the cavity, and the reactant-electrolyte flowed through the structure.

Structure 2 proved to be the best for the bromine-bromide and copperammonium complex couples; structure 3 was most suitable for the iron couple.

During the experimental work at Lewis, the question arose. whether the crossmixing of reactants through the membranes, in addition to affecting the coulombic capacity of the cell, had some additionel effect on the cell performance. This led to the development of the three-stream cell (fig . 4), in which two membranes are used to more effectively isolate each half-cell from the reactants of the other. Performance of the three-stream cell and the standard cell configuration, under identical conditions and with the iron-titanium pair, is compared in figure 5 . In this comparison it was noted that the reactant. crossmixing rate was decressed by a factor of 10 for the three-stream cell. The greatly superior performance of the three-stream coll was unexpected, in that It has two membranes interposed between the electrodes, instead of one. There is evidence, discussed in the next section, thet the poorer per- 


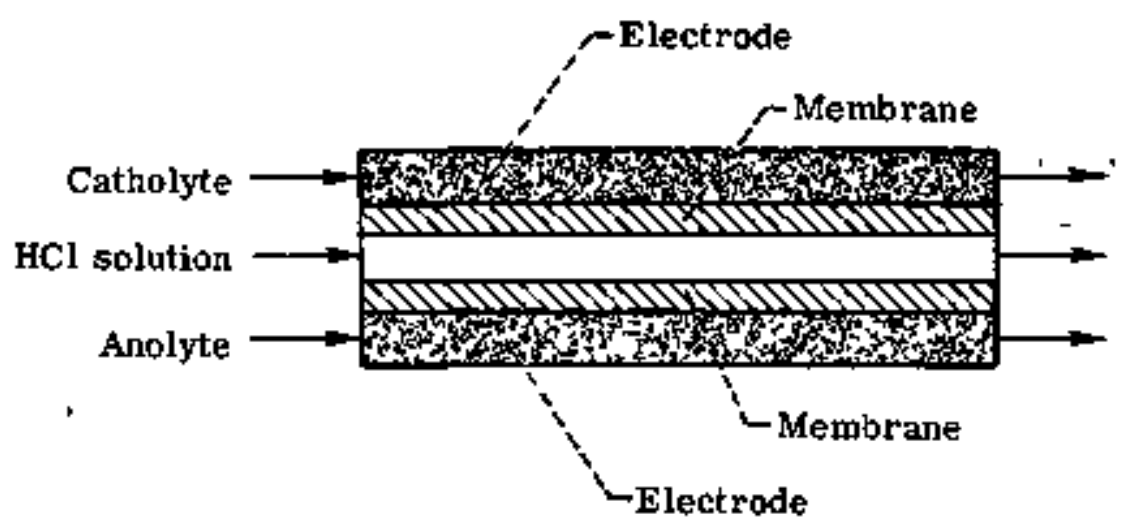

Figure 4. - The three-stream cell.

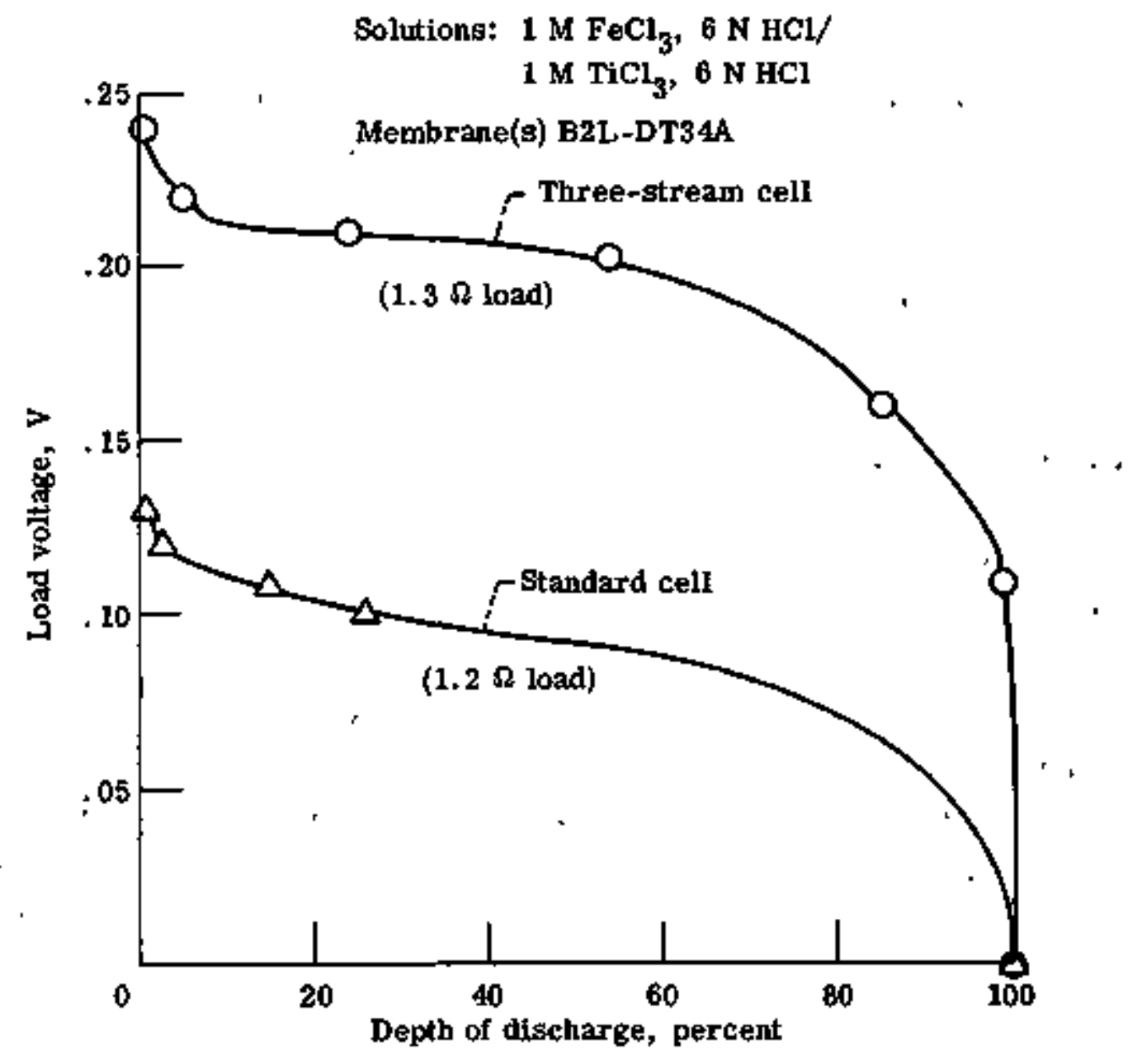

Figure 5. - Performance comparison of three-stream' and standard redox cell configurations. 
formance of the standard cell is not due to the crossmixing of reactants, per se, but to the interaction of the two reactants within the single membrane.

In the case that a less-than-perfect membrane is developed for redox application, the three-stream configuration presents a very attractive fall-back position. From a system standpoint, the reactants that escape the respective half-cells are swept away by the acid solution flowing slowly between the membranes. These reactants could possibly be separated in an ion-exchange column and returned to their respective storage tanks.

To simplify cell fabrication and to reduce cell thickness and internal resistance, some development work was done on "composite membranes." In these, large-surface-area catalytic electrode material is bonded directly to the surfaces of an ion exchange membrane (fig. 6). Materials examined were carbon powder and paper; graphite powder, fiber, and felt; and palladium powder. These materials were bonded to ion-exchange membranes or microporous membranes by solvent-slurry coating or hot pressing. In cells with the iron-titanium pair, the voltage-current performance of hot-pressed graphite fiber or felt on microporous polyvinylchloride films was equivalent to that of the standard test cell. A similar composite membrane using palladium powder initially gave twice the performance of the standard cell, but the metal slowly dissolved in the acidic electrolyte.

Although these composite membranes offer some interesting possibilities, they proved difficult to fabricate. At present, no further work is being done in this area.

\section{Electrolyte (Reactant) Solutions}

When evaluation of the iron-titanium couple pair first began at Lewis, it was decided to use $0.5 \mathrm{~N} \mathrm{HCl}$ as the supporting electrolyte for the iron couple, and $6 \mathrm{~N} \mathrm{HCl}$ for the titanium couple. It was felt that this was necessary to minimize the formation of anionic iron chloride complexes which might pass with ease through the anion-exchange membrane and to prevent the precipitation of titanium dioxide. At that time the chemical analyses discussed in section II were not yet in use, so it was not realized that equilibration would 


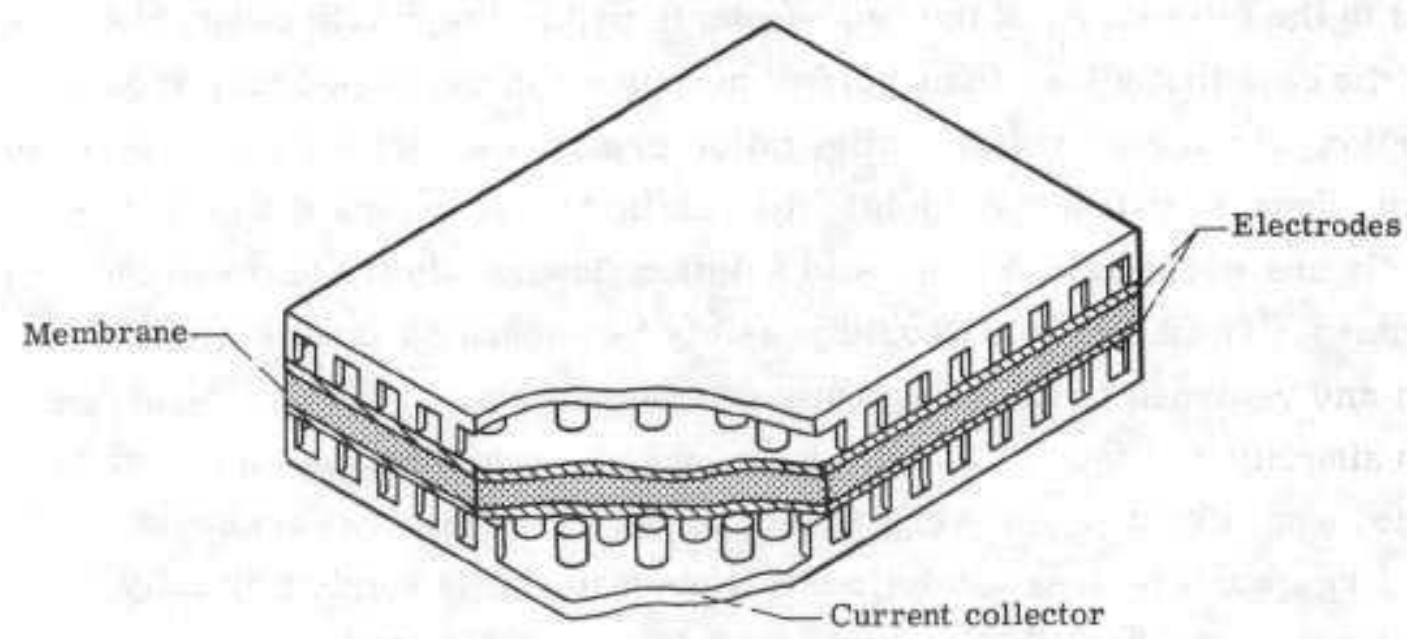

Figure 6. - Redox cell with composite membrane.

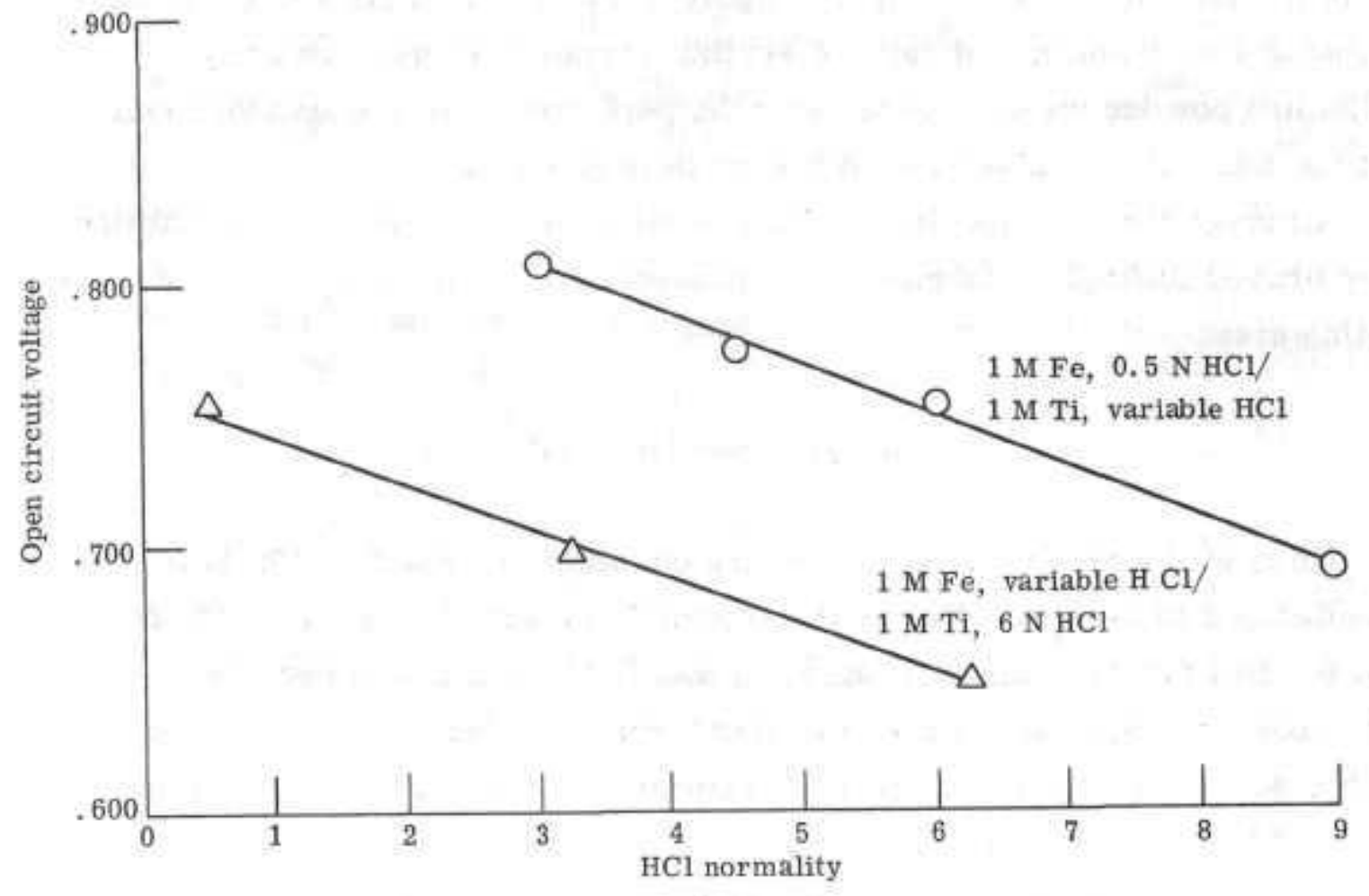

Figure 7. - Effect of $\mathrm{HCl}$ concentration on initial iron-titanium cell open-circuit voltage. 
quickly bring these two acid concentrations to about $3 \mathrm{~N}$. Therefore, tests were made to determine whether this choice of acid concentrations was detrimental to cell performance. Figure 7 shows that increasing the acid concentration in either reactant causes decrease in cell open-circuit voltage. However, figures 8 and 9 , showing the effect of acid concentration on load voltage, reveal that, in fact, the choice of $6 \mathrm{~N} \mathrm{HCl}$ for the titanium electrolyte and $0.5 \mathrm{~N} \mathrm{HCl}$ for the iron electrolyte was a good one. These last two figures also show that once the electrolytes equilibrate to about $3 \mathrm{~N} \mathrm{HCl}$, cell performance has become quite poor. To determine how rapidly this equilibrium occurred, a cell with the $0.5 \mathrm{~N}-$ to-6 $\mathrm{N}$ acid gradient was compared with one in which both electrolytes had $6 \mathrm{~N}$ acid. Figure 10 shows that the cell with the acid gradient suffered considerable performance loss during early cycles, while the performance of the cell with no gradient was quite stable.

These results explained, in part, an often-noticed problem with the iron-titanium couple pair: a rapid cycle-to-cycle loss in cell performance during the early stages of cell testing. To determine whether any other phenomena were occurring in addition to the equilibration of acid concentrations, two "common ion" cells were evaluated. In these, the oxidized form of a redox couple (e.g. . Fe ${ }^{+3}$ ) was the cathodic reactant and the reduced form (e.g . , $\mathrm{Fe}^{+2}$ ) was the anodic reactant. In each cell the acid concentration was the same on both sides of the membrane in order to eliminate equilibration as a factor in cell performance. Figure 11 shows that the first five discharges for the iron common-ion cell were virtually identical. However, as shown in figure 12, there was a loss of about $110 \mathrm{mV}$ during the first four discharges of the titanium cell. The causes of this behavior are not yet completely understood, but oxidation of the titanous ion by dissolved air is a probable contributor. Anyway, the titanium half-cell now has been positively identified as the source of the time-dependent loss of performance in cells with the iron-titanium couple pair.

It is quite likely that no membrane will be developed that has perfect selectivity (i.e., that completely eliminates crossmixing of reactant ions). To determine the ultimate effect of such crossmixing, a cell was run in which the iron and titanium solutions were premixed. The performance of this cell 


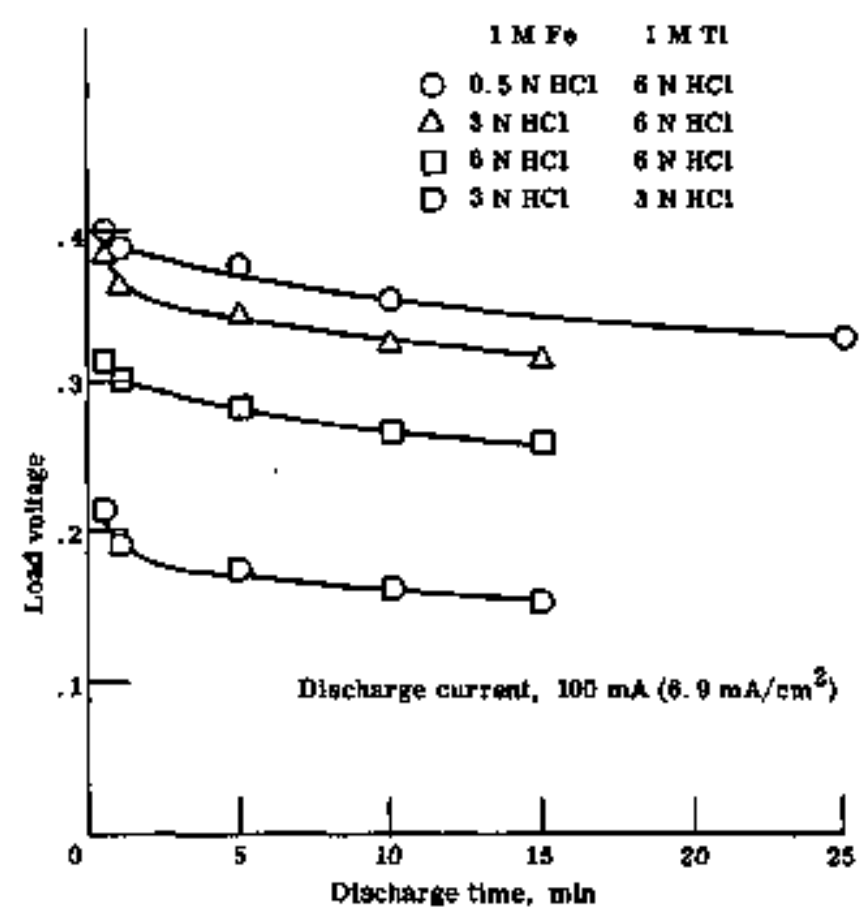

Flnite B. - Etteck on cell performance of BCl concertration in the iron electralyte.

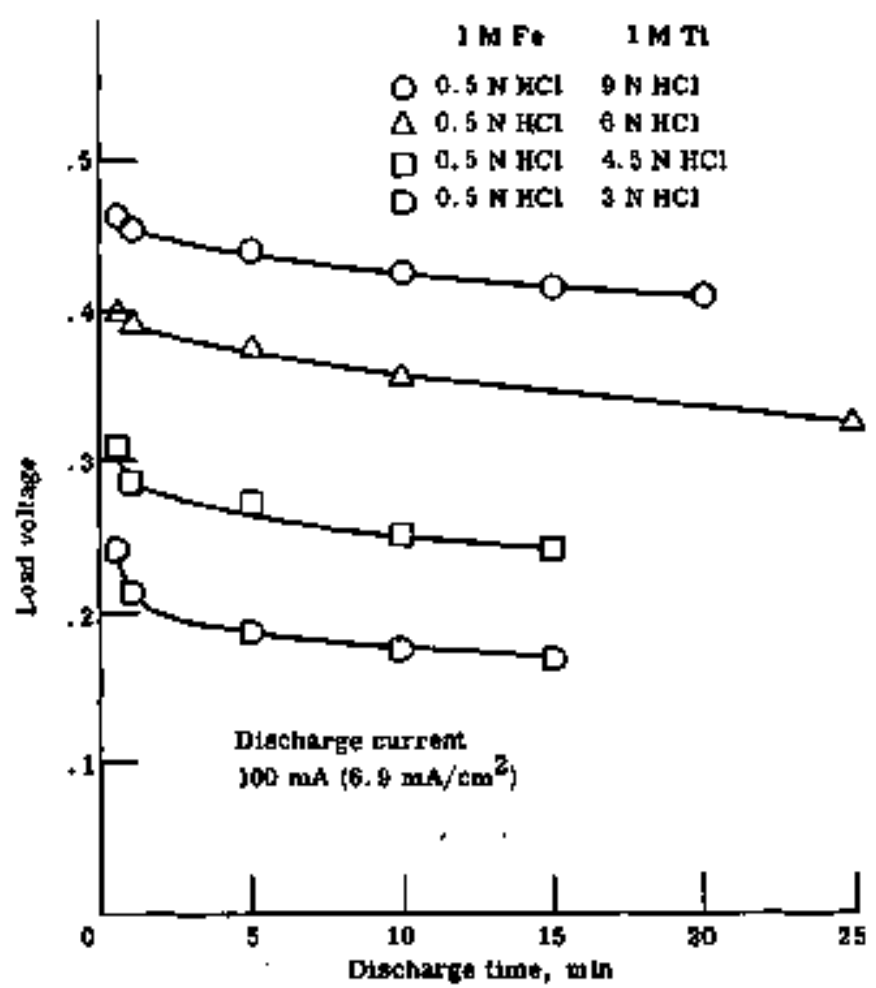

Figure 9. - Effect on cell pertormance of BC1 concentraLion in the titansum electrobyte. 


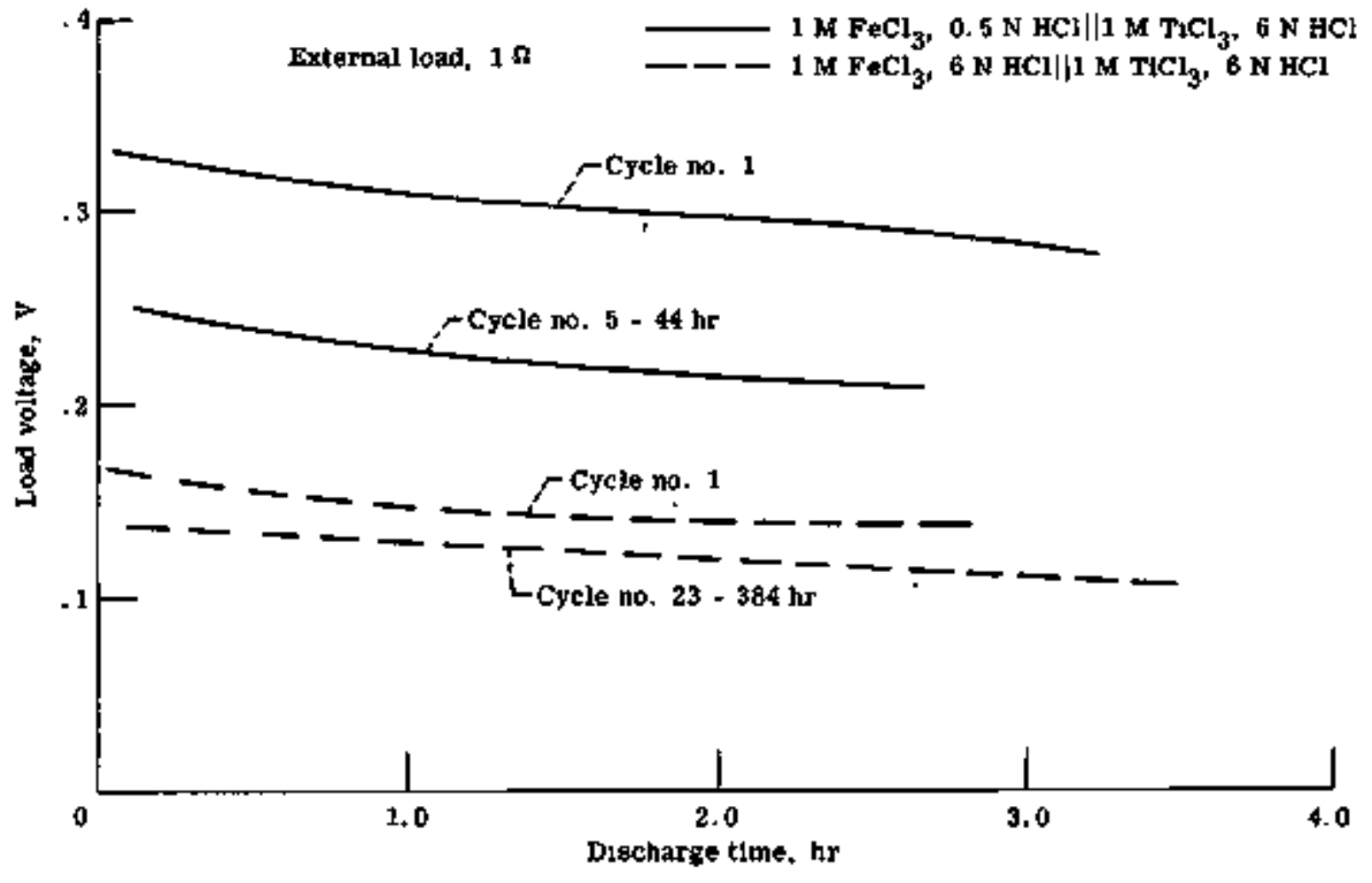

Figure 10. - The elfect of acid gradient equilibration on cell performance. 


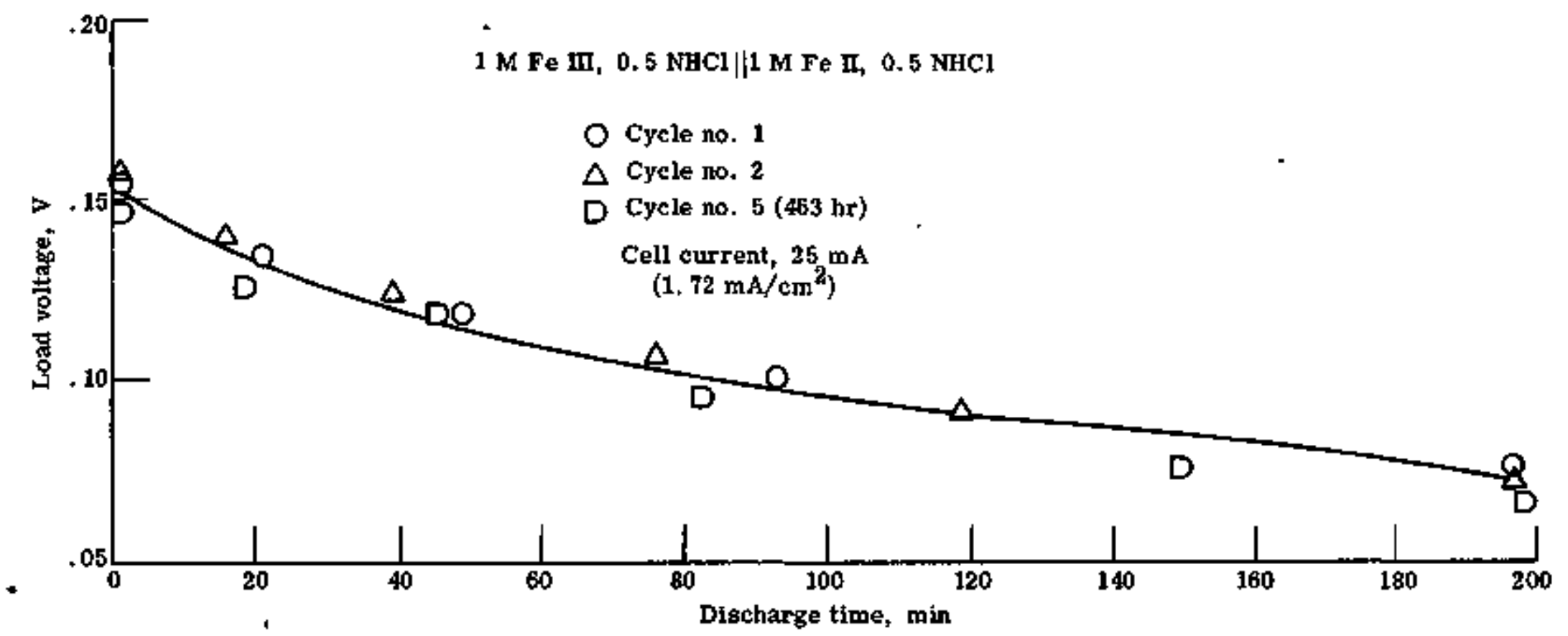

Figure 11. - Cycle reproducibility for the iron common-ion cell. 


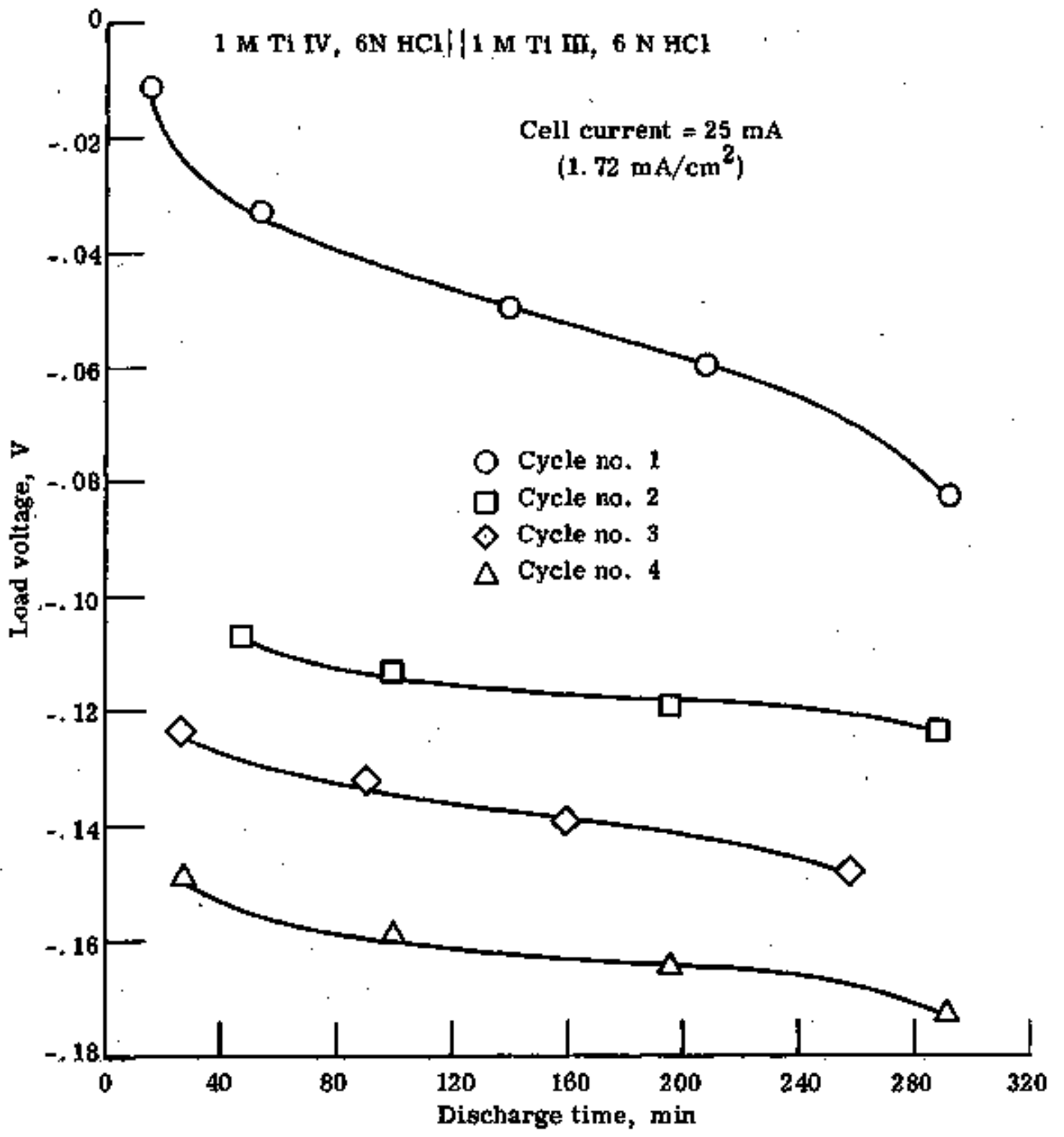

Figure 12. - Cycle reproductbility for the titanium "common-ion" cell. 
is compared with that of a cell with fresh, unmixed reactants in flgure 13. Although complete solution mixing resulted in a loss of about $40 \mathrm{mV}$ in open-circuit voltage at various levels of discharge, the loss in load voltage was less than $10 \mathrm{mV}$. The Implication of this result is that the degree of crossmixing, per se, has very little effect on cell performance, However, the performance comparison of a standard cell heving fresh, unmixed reactants and a three-stream cell (fig. 5) showed a 100-mV advantage for the three-stream cell (i.e., the cell in whoh neither membrane nor electrode is exposed to both reactents). It seems, then, that there are two major problems with a cell of standard configuration when the iron-titanium couple pair is used:

(1) There' is an immediate performance penalty, which restults efther from the exposure of the membrane to both concentrated reactants and/or from the exposure of one (or both) of the electrodes to minute amounts of the crossingover reactant.

(2) There is an additional, as-yet unexplained, loss of performance for the titanlum half-cell during early cycles. There was also an early operational problem with the iron-titanium couple pair, one to the ease of chemical oxidation of the $\mathrm{T}^{+3}$ ion. The diffusion of air into the cell test system was causing "ohemical discharging" of the titanium couple. The cell would then accept only enough electrical charge to recharge the iron couple, leaving the titanium couple in a partially discharged state and indicating a loss of capacity. For testing purposes, this problem was alleviated by using a nitrogen blanket for the test system and by using an excess of charged titanium solution. In this way it was possible to operate for extended perlods of time, always having sufficient $\mathrm{Ti}^{+3}$ avallable to match the capacity of the iron halfcell. :

\section{SNALL-SCALE SYSTEM EXPERIMENTS}

\section{Multicell Stacks}

An analytical study at Lewis (ref, 5) has shown that when redox cells are connected hydraulically in parallel between common electrolyte manifolds. 


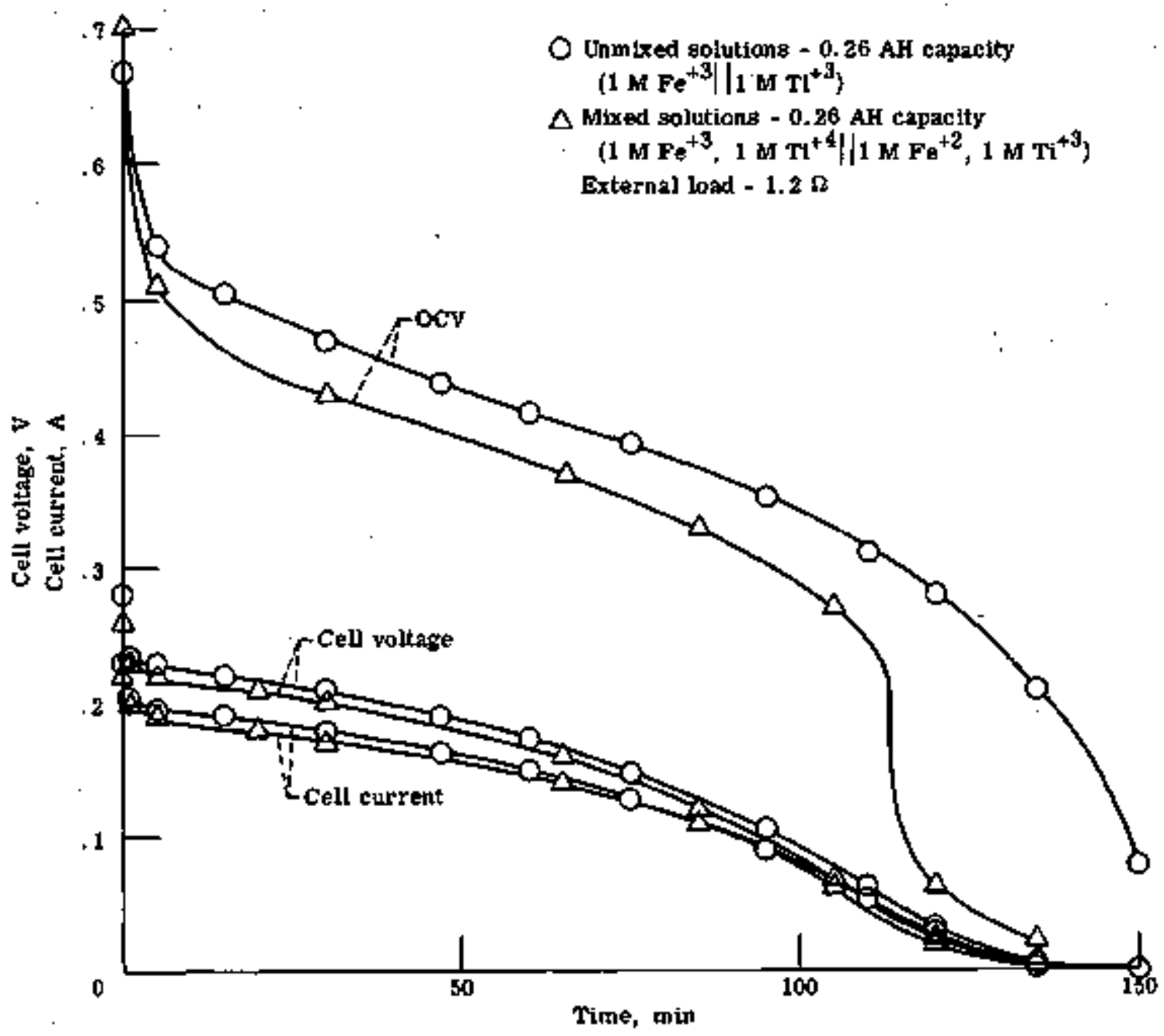

Figure 13. - Performance comparison of mixed reactants with unm lxed reactants. 
parasitic circulating currents will develop. If inadequate attention is given to the design of the manifolds and cell reactant ports, these circulating currents can represent a significant loss in power and capacity .

A six-cell stack (fig. 14) with high-resistance (large L/D) reactant ports was designed, assembled, and evaluated for circulating current losses. The evaluation consisted of measuring the stack voltage first with the cell reactant cavities and manifolds flooded and then with the cavities nooded but with the manifolds drained. When the manifolds were flooded, which allowed the circulating currents to exist, the stack voltage was about 0.5 percent less than when the manifolds were drained. 'This result compared well with the prediction of the model and gives encouragement that the circulating current problem can be minimized. However, there will be a trade-off against the greater pump power necessitated by the high-resistance cell resctant ports .

\section{Redox Storage for Solar Photovoltaic Array}

. At the request of the Photovoltaic Technology Branch at Lewis, a laboratory-scale redox system (fig. 15) was designed to provide energy storage for a solar cell array. The design concept was to use two separate redox cells sharing common reactant solutions. One redox cell was to deliver power continuously to a fixed-resistor load, while the other was to recharge the reactant solutions. A simple relay was used to isolate the charging redox cell from the solar cell array when the array output voltage fell below a preset value. This prevented the charging redox cell from discharging through the array. The test stand (fig. 16) was designed to continuously monitor the solar cell array electrical output and the current, voltage, and integrated ampere-hours tor the two redox cells. The combined systems operated continuously for 2 months (ref. 6) and presented neither operational nor interface problens. These encouraging results suggest that a redox system can be a technically viable storage candidate for solar photovoltaic power generation. 


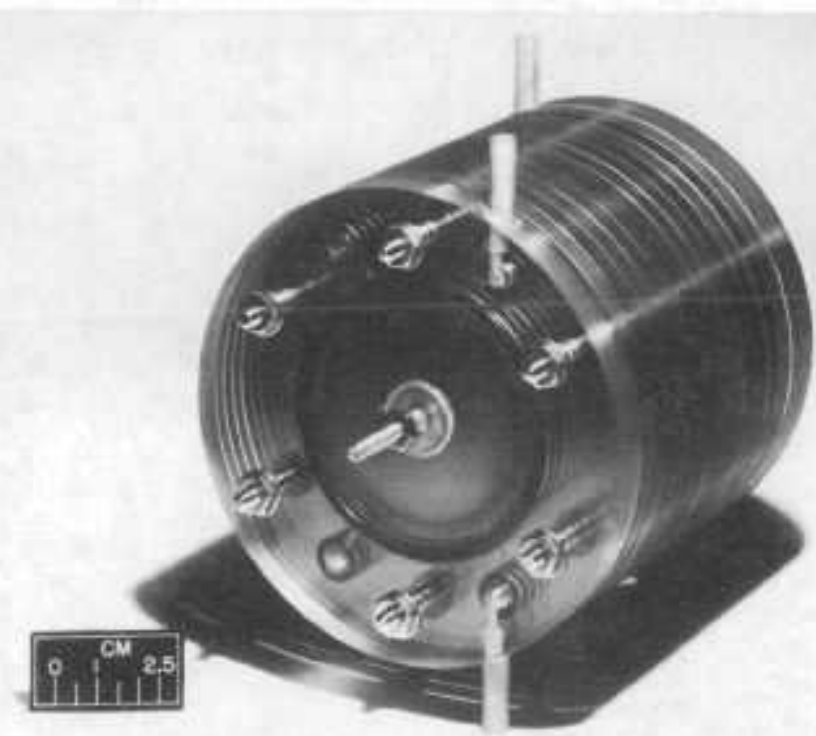

Figure 14. - Stack of six redox cells, hydraulically in parallel.

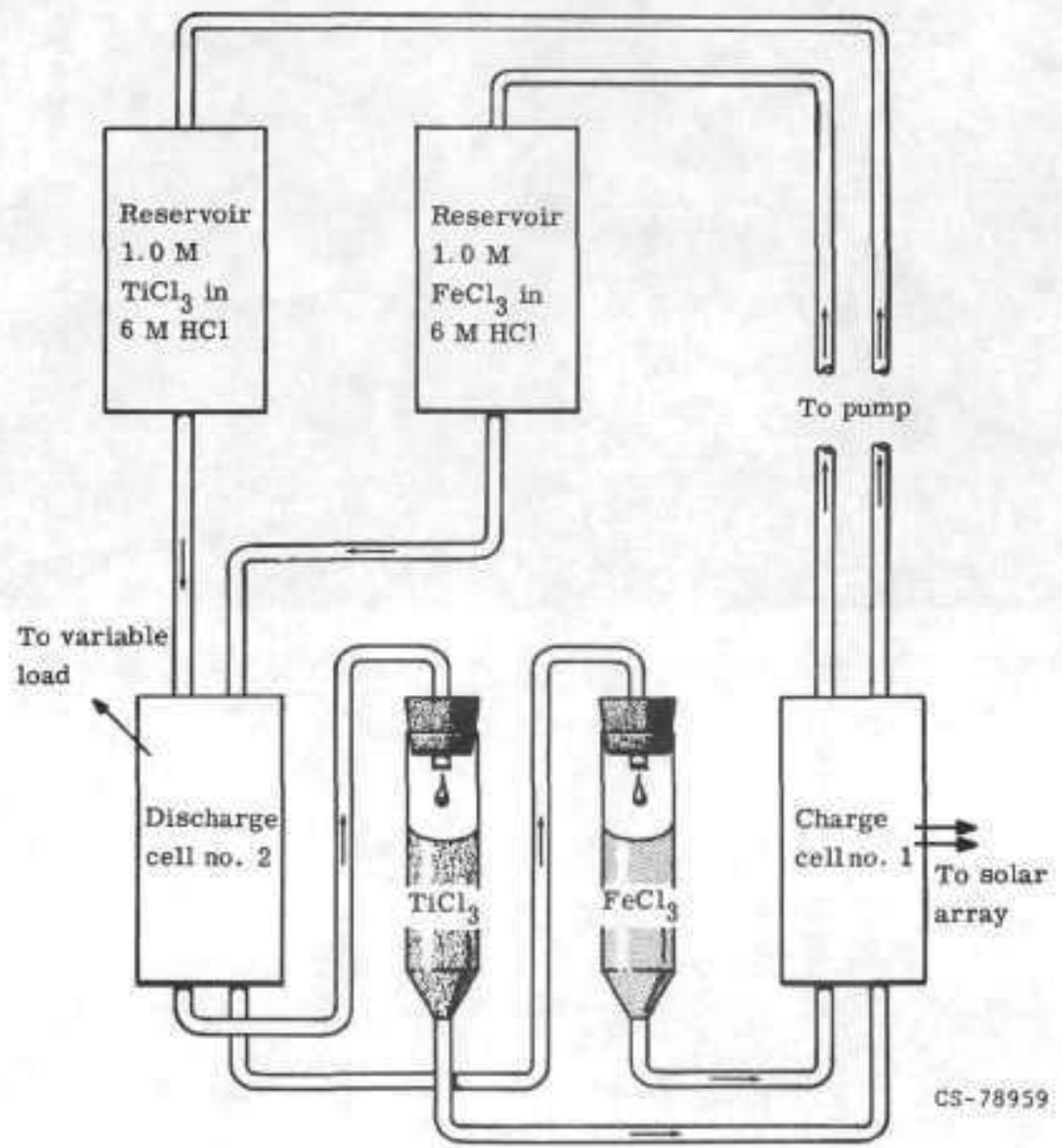

Figure 15. - Redox energy storage system for solar photovoltaic power source. 


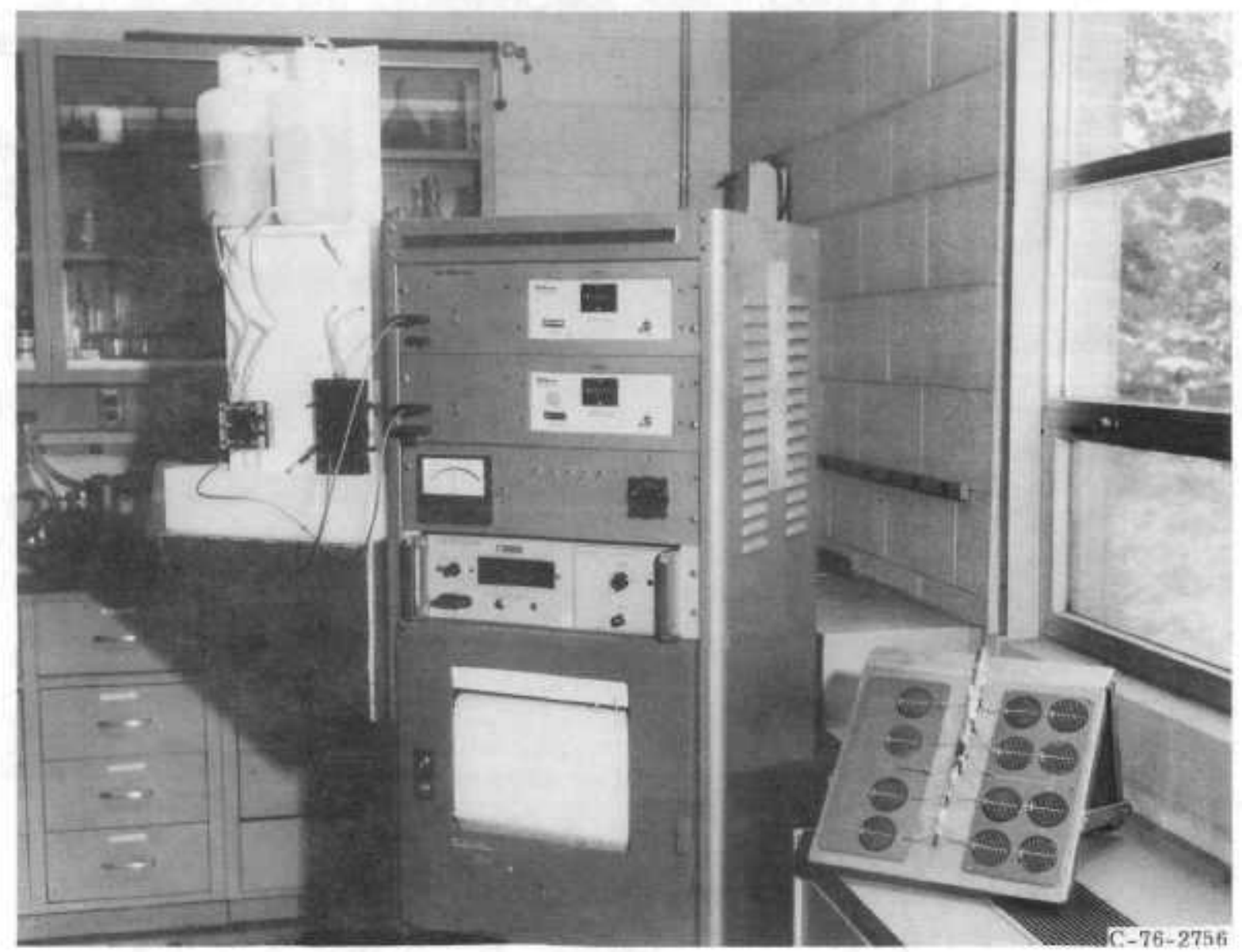

Figure 16, - Test stand for combined redox and solar photovoltaic systems. 


\section{SYSTEM STUDIES}

The primary purpose of this effort was to develop a series of computer models of the redox system. Each model represents an increase in the level of sophistication over the preceding versions. These models are being used to identify the parameters to which system cost is most sensitive. This information will permit the establishment of cell performance goals and cell component characteristic goals for the redox cell development effort. Also, an extensive bibliography has been developed of literature on electric utility operation, electrochemical technology, and the various methods proposed for electrical energy storage. In addition, a tabulation has been prepared of the requirements which must be met by a storage system in order to be attractive to the electric utilities. Finally, an inclusive collection of comparative data for electrochemical devices proposed for utility storage applications has been compiled and analyzed. The major portion of this work was performed under contract by the Government Research Laboratories of the Exxon Research and Enginesring Co., with consultation by the Public Service Electric and Gas Co. (PSE\&G).

The first redox system model in this effort was developed at Lewis (ref. 7 ) and is referred to as the Stage Zero model. In a slightly modified form this model was programmed for the computer and was used in a preliminary parameter sensitivity analysis. The results of this analysis (fig. 17) show a large effect on system cost for variations in cell operating voltage, system voltage, and cell current density.

The next system model (Stage 1) was developed in outline form at Lewis and represented the starting point for the contract effort with Exxon Corp . The Stage 1 model assumed time-averaged values for all system parameters such as voltage, power level, and electrolyte concentrations. In its initiel form the model was limited to the simulation of daily cycles only. Subsequent modifications enabled the modei to accommodate weekly cycles consisting of fixed daily charge/discharge power levels and variable daily charge/discharge times. Optimization routines are used to find the charging current density that results in minimum system cost. These additional capabilities of the 


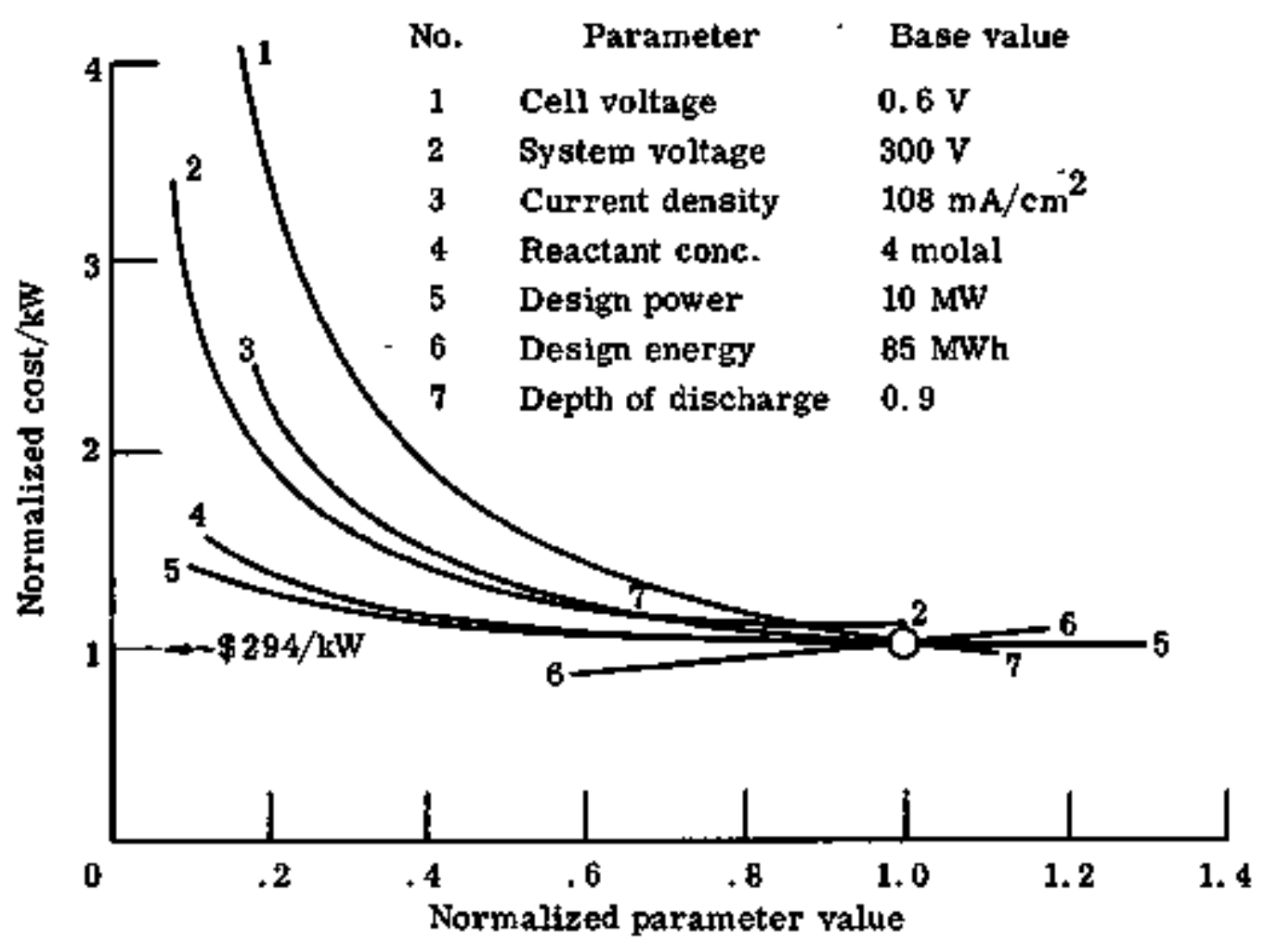

Figure 17. - Redox system parameter sensitivity. Stage zero model.

TARLE 5. - hATIFG GRITERIA FOR EBLAFL ISHING FIGURE OF MERTT

FOR SELECTED BATTERY SYSTEMS

\begin{tabular}{|c|c|c|}
\hline Parameter & $\begin{array}{l}\text { Value of } 1 \\
\text { Assigned } 1 \mathrm{f} \text { : }\end{array}$ & $\begin{array}{l}\text { Value of } 2 \\
\text { Assigned if: }\end{array}$ \\
\hline Aversge operating voltage, $v$ & $\leq 1,00$ & 21.00 \\
\hline 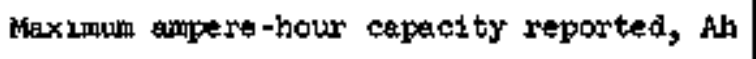 & $\leq 200$ & 2100 \\
\hline opersting temperature, ${ }^{\circ} \mathrm{C}\left({ }^{\circ} \mathrm{r}\right)$ & $2100(212)$ & $\$ 100(212)$ \\
\hline Grele life, number of cycles & $\leq 1000$ & 21000 \\
\hline Depth of discharge, percent & $\leq 50$ & 250 \\
\hline Watt-hour efficiency, percent & $\leq 75$ & 275 \\
\hline Energs density, wh/kg $(W h / 1 b)$ & $\leq 55(\leq 25)$ & $\geq 55(\geq 25)$ \\
\hline Fower density, w/kg (w/1b) & $555(s 25)$ & $255(225)$ \\
\hline Cost, $\$ /$ hWh & 250 & $\leq 50$ \\
\hline
\end{tabular}


modified version of the Stage 1 model should make it a useful tool for examining the operational flexibllity and design possibjlities of the redox concept .

The original and modified versions of the Stage 1 model have been used by the contractor and at Lewis to examine the sensitivity of system cost to changes in system design parameters. The conclusions reached as a result of these studies have been reported in the contractor reports and in the monthly Management Information and Control System (MICS) reports prepared at Lewis for NASA and DOE Hegdquarters. However, it recently has been determined that some of the subroutines for calculating the costs of certain system components are in error and have been generating excessively high numbers. As a result, many of the conclusions reached and reported concerning the cost of redox systems and the effect of certain operational parameters on these costs are badly distorted. The models will be corrected and the studies repeated.

The Stage 2 model, which still is being developed, will be able to handle any charge/discharge power profile. It will take into account the effect of time-dependent reactant concentrations on electrochemical parameters (polarizations, current density, etc.) and the effect of hydrodynamfe conditions on cell mass transport .

Performing a comparative analysis of available data for the possible electrochemical devices for energy storage was made difficult by the differing levels of the state of the art for the respective systems. However, by applying the criterta in table 5 to the collected data, the following systems were determined to be attractive candidates:

Lead-acid

Zinc-haloger

Metal-air

Alkeli metal sulfides

Redox

The requirements which must be met in order for a storage system to be attractive to the electric utilities are presented in tables 6 to 10. These data represent values or ranges of values derived from the study of a broed spectrum of electric utikities throughout the Nation. Included in the tables 
TABLE 6. - RAKGSS OF STORACF SYSTEM DITY CYCHE OPRRATTIG PARAMETERS SUPPORTABLE ON U. S. BLECTRIC UTILITY SYSTEMS

\begin{tabular}{|c|c|c|c|c|}
\hline \multirow{3}{*}{$\begin{array}{c}\text { Duty-cycle } \\
\text { characteristics }\end{array}$} & \multicolumn{4}{|c|}{ Type of operation } \\
\hline & \multicolumn{2}{|c|}{ Intermediate duty } & \multicolumn{2}{|c|}{ Feaking duty } \\
\hline & Datiy cycle & Weerly cycle & Daily cycle & Weekly cycle \\
\hline $\begin{array}{l}\text { Digcharge time, b/day } \\
\text { Grice time, h/dgy: } \\
\text { Weekagy } \\
\text { Wegkend }\end{array}$ & 5 to 9 & $\begin{array}{l}9 \text { to } 14 \\
5 \text { to } 9 \\
14 \text { to } 34\end{array}$ & 5 to 9 & $\begin{array}{l}1 \text { to } 9 \\
5 \text { to } 9 \\
14 \text { to } 34\end{array}$ \\
\hline $\begin{array}{l}\text { Ratio of charge power to } \\
\text { discharge power }\end{array}$ & 1.3 to 3.7 & 0.8 to 2.4 & 0.15 to 2.4 & 0.1 to $1.5^{\prime}$ \\
\hline $\begin{array}{l}\text { Storage capability, } h \\
\text { Anmugl operation (annugl } \\
\text { discharge time), } h\end{array}$ & $\begin{array}{c}9 \text { to } 14 \\
2300 \text { to } 3600\end{array}$ & $\begin{array}{c}17 \text { to } 47 \\
2300 \text { to } 3600\end{array}$ & $\begin{array}{c}1 \text { to } 9 \\
250 \text { to } 1000\end{array}$ & $\begin{array}{c}2 \text { to } 30 \\
250 \text { to } 1000\end{array}$ \\
\hline
\end{tabular}

apor storage systems with turnaround efflciency of 75 percent.

TABISE 7. - TIE-DA VOLTAGE AND FOWKR LWVR FOR UTIITY EMERGY STORACE APPLICATIONS

\begin{tabular}{|c|c|c|}
\hline $\begin{array}{l}\text { Storage system } \\
\text { locations" }\end{array}$ & $\begin{array}{c}\text { Connection }(t 1 *-i n) \\
\text { voltage, } \\
\mathrm{kV}\end{array}$ & $\begin{array}{c}\text { Discharge power } \\
\text { level, } \\
\text { rw }\end{array}$ \\
\hline $\begin{array}{l}\text { Substation } \\
\text { Switehing station } \\
\text { Central station }\end{array}$ & $\begin{array}{l}4 \text { to } 34.5 \\
26 \text { to } 230 \\
138 \text { to } 500\end{array}$ & $\begin{array}{l}b_{10} \text { to } 100 \\
b_{10} \text { to } 200 \\
\text { soo to } 2000\end{array}$ \\
\hline
\end{tabular}

Intermediate end peaking duty and dajly and weekly cycle storage systems all appear to be useful at encili location.

The lareer power levels would probably apply to weekly atorage cycles.

The laxger power.lepels represent the naximun power. arsosiatod with current pumped-water storage technologr. 


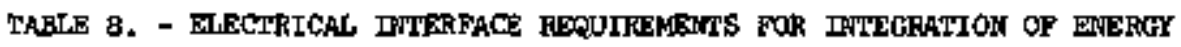

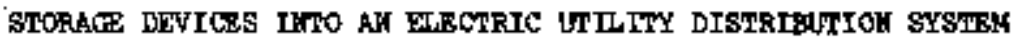

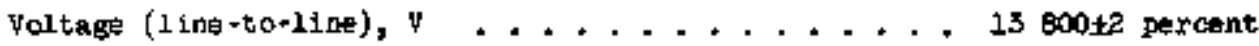
Frequency, Hz.......................... 6010.1

Reactive powst exchangs whth aternat1ng-current system, UVAR .............................. tz Herminick, jercent:

Plus maxjmm single valtage ... . . . . . . . . . . . . . . . ll

Plis maximon totel voltage .........................

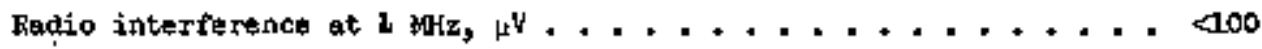

Audible (adjusted) nolse at property 1ine, dBh $\ldots+\ldots, \ldots+\ldots$

Basic impalae insulation level, $\mathrm{kr}$ :

BI ................................... 20

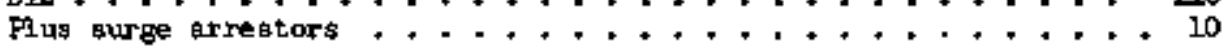

Short-circult wurent 1init, percent of rated

current............................. 410

TARLE 9. - BREAK-EVEH CAPITAL COST RARET FOR BATTERY BMERGY

SH'UkALE SYSTEMS IN FRAKING DUTY

\begin{tabular}{|c|c|c|c|}
\hline \multirow{2}{*}{$\begin{array}{c}\text { Annugl } \\
\text { operat ing } \\
\text { tipe, } \\
\text { it }\end{array}$} & \multirow[t]{2}{*}{$\begin{array}{l}\text { Noninal battery } \\
\text { discharge capacity, } \\
\text { h }\end{array}$} & $\begin{array}{l}\text { Ifeat-term } \\
(1976-85) \text { lesd- } \\
\text { sc1d bettery }\end{array}$ & $\begin{array}{c}\text { Intermediate-term } \\
\text { (19es-2000) advanced } \\
\text { battery }\end{array}$ \\
\hline & & \multicolumn{2}{|c|}{ Break-even capital cost, $\$ /$ w } \\
\hline wod & 2 & 50 to 120 & 240 to 240 \\
\hline 1000 & 5 & 50 to 230 & 210 to 440 \\
\hline 2000 & 10 & 50 to 410 & 310 to 790 \\
\hline
\end{tabular}

TAELE 10. - BREAK-EVEM CAPTTAL COST RAHGS FOR BATTERY BHERGY

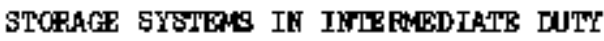

\begin{tabular}{|c|c|c|c|}
\hline \multirow{2}{*}{$\begin{array}{l}\text { Annugal } \\
\text { operating } \\
\text { time, } \\
\text { h }\end{array}$} & \multirow[t]{2}{*}{$\begin{array}{l}\text { Nominal battery } \\
\text { dischar ofe capteity, } \\
h\end{array}$} & $\begin{array}{l}\text { Hear-term } \\
\text { (1976-85) lead- } \\
\text { acld battery }\end{array}$ & $\begin{array}{l}\text { Inter wodiate-terw } \\
\text { (1985-2000) atvanced } \\
\text { battery }\end{array}$ \\
\hline & & \multicolumn{2}{|c|}{ Break-ewen tapital epst, $\$ / k H$} \\
\hline-2500 & 10 & 20 to 430 & 330 to 930 \\
\hline 3000 & 32 & 0 to 490 & 350 to 950 \\
\hline 4000 & 15 & -40 to 620 & 390 to 1190 \\
\hline
\end{tabular}


are ranges of duty-cycle parameters, tie-in voltage and power levels, electrical interface requirements, and break-even cost goals.

\section{HYDRODYNAMICS}

The effort in the area of hydrodynamics has been to evaluate the effect on cell performance of the redox reactant flow characteristics and the cell design parameters. The work performed was mainly èxperimental, with some supporting analytical studies. The $\mathrm{Fe} / \mathrm{Ti}$ redox couple pair was used in all the tests. The baseline cell configuration consisted of a carbon cloth electrode

. Hush against each side of a membrane, and a grooved reactant flow plate adjacent to each cloth electrode. The flow plates, which also served as current collectors, were wax-impregnated graphite plates with 0.32 -centimeter(1/8-in. - ) deep machined flow grooves separated by 0.32 -centimeter (1/8-in.) lands.

Five plates were fabricated having, respectively, the following number and width of grooves:

\begin{tabular}{|c|cc|}
\hline $\begin{array}{c}\text { Number } \\
\text { of groover }\end{array}$ & \multicolumn{2}{|c|}{ Width } \\
$\mathrm{cm}$ & in. \\
\hline 3 & 1.27 & $1 / 2$ \\
5 & .64 & $1 / 4$ \\
7 & .32 & $1 / 8$ \\
10 & .16 & $1 / 16$ \\
12 & .08 & $1 / 32$ \\
\hline
\end{tabular}

Each flow groove traced a block- $\$$-shaped path across the 14-centimeter (5.5-in.) by 14-centimeter (5.5-in.) electrode surface. The apparatus used in the experiments is shown in figure 18.

The first screening tests consisted of measuring constant-current discharge performance while maintaining the reactant flow rate and the plate configuration constant on one side of the cell and varying flow rate and plate configuration on the other side. In all cases the cell response was 


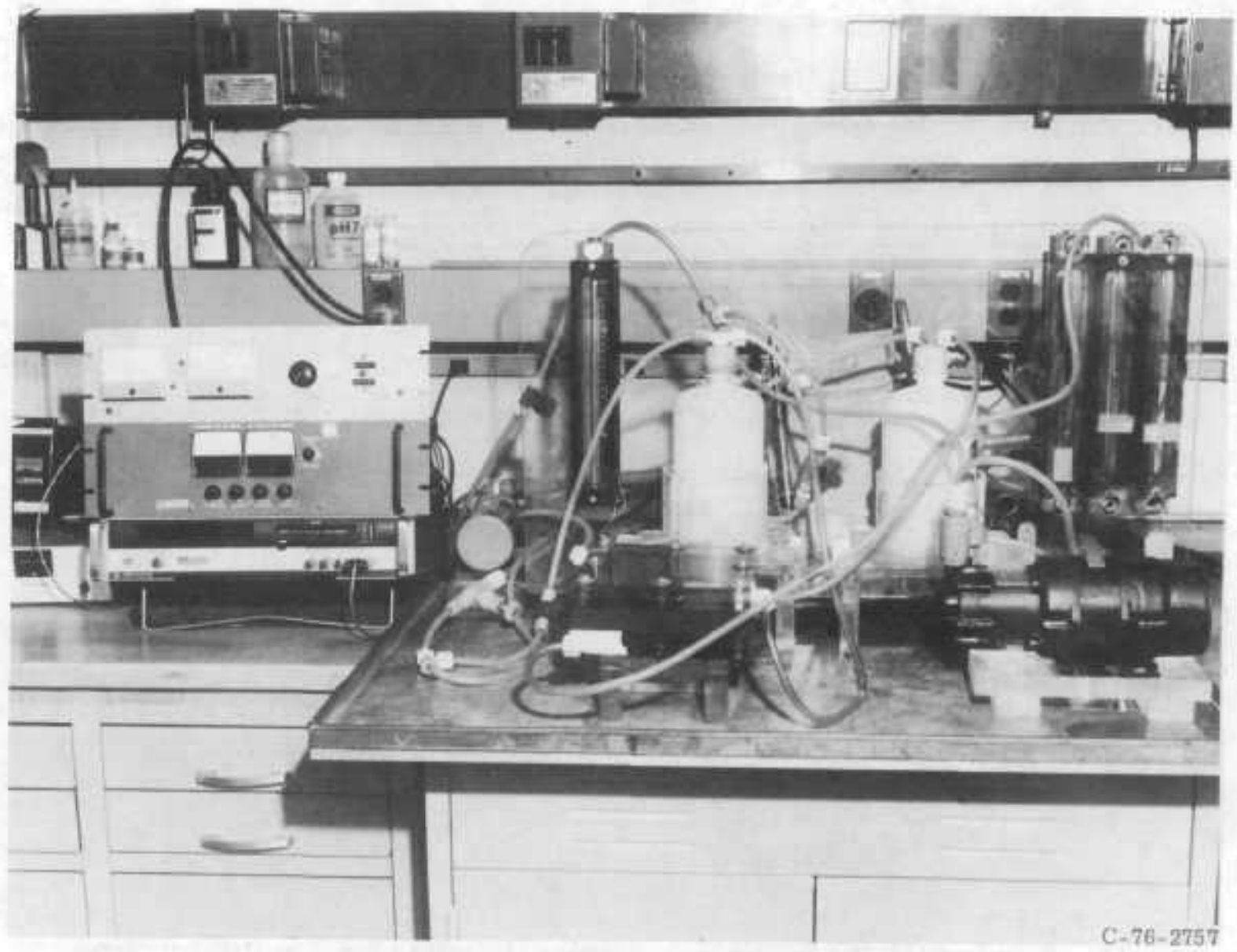

Figure 18. - Experimental set-up for hydrodynamics studies. 
sluggish when going from open circuit to load. Also, performance was very poor at reactant flow rates that were, though low, still five to ten times greater than the stoichiometric requirement. This latter effect was predicted by a laminar flow model which indicated severe reactant depletion in the diffusion boundary layer when the bulk reactant concentration was as low as $1 \mathrm{M}$. The use of reference electrodes revealed that the sluggish cell response was associated almost completely with the titanium half-cell. Several cell modifications to induce flow turbulence or to make the electrodes a flowthrough type were evaluated:

(1) Baffling the reactant flow repeatedly through the cloth electrode

(2) Reducing the flow groove depth to 0.08 centimeter (1/32 in.)

(3) Placing turbulence-promoters in the flow grooves

(4) Removing the cloth electrodes and filling the flow grooves with graphite chips or strips of graphite felt. Of these modifications, the first and fourth, which resulted in flowthrough electrodes, were particularly effective in permitting low-flow-rate operation. The flowthrough electrodes also virtually eliminated the sluggish cell response characteristic. The results for the final set of tests are shown in figure 19. These curves illustrate the advantage of using concentrated reactant solutions and flowthrough electrodes .

Upon DOE's programmatic direction, further work under this effort has been postponed for the present, in order to concentrate on other issues.

\section{FACILITY PREPARATION}

Early planning for the Lewis redox program called for a multipronged approach to the development of a functional redox system. One aspect of this approach was long-term testing of scaled-up redox cells. It was decided that a new facility should be prepared for this testing, permitting unattended operation of cells for extended periods. The facility was to be capable of controlling the simultaneous testing of six redox cells or cell stacks. The facility (funded by NASA) has been completed, along with the first of the six test stands. A 929-square-centimeter $\left(1-\mathrm{ft}^{2}\right)$ cell was operated for several days to check out the test stand, the associated control subsystems, and the 


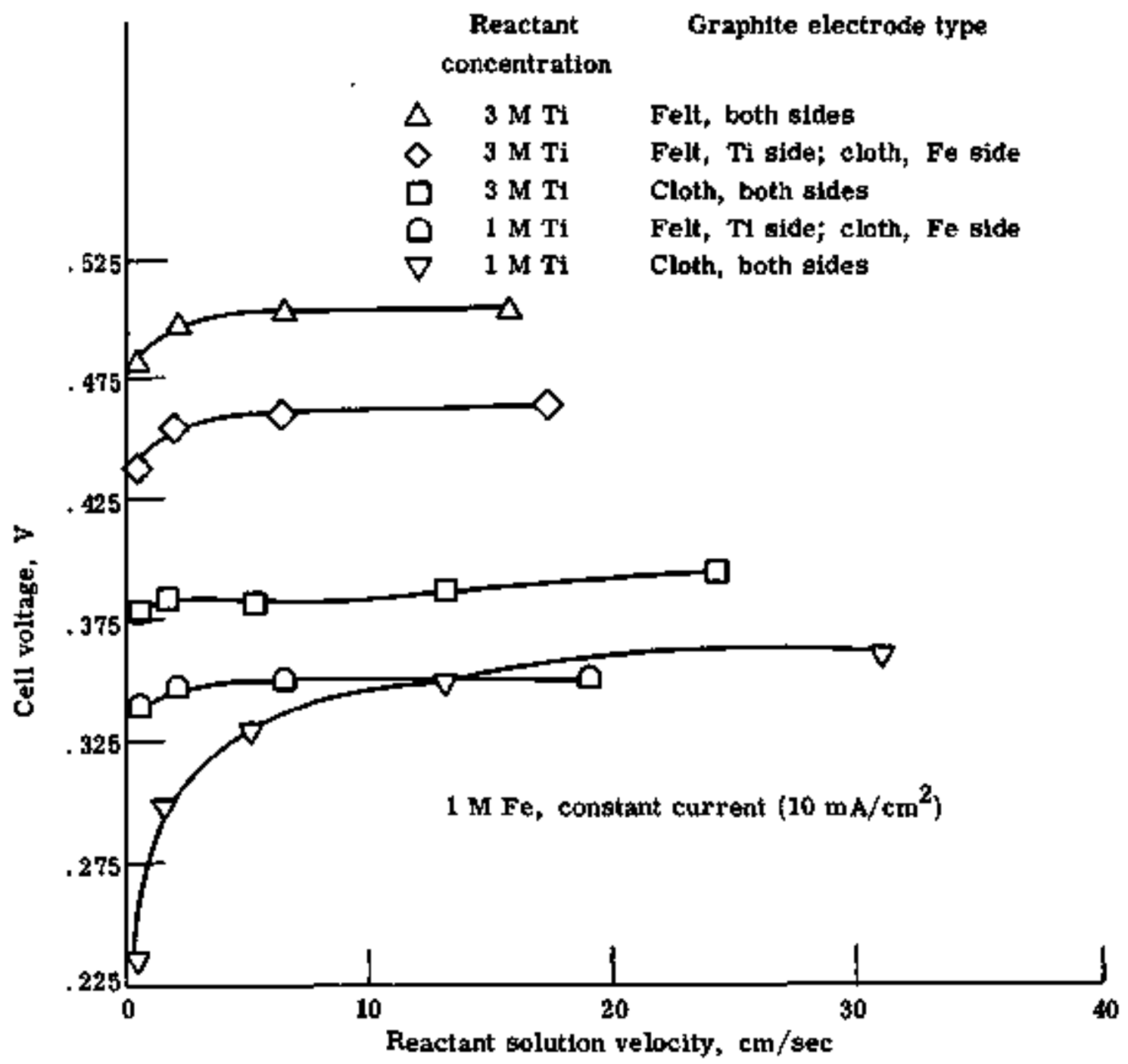

Figure 19. - Effect of reactant flow rate and concentration and electrode type on redox cell performance. 
data management subsystem. The facility was then placed in a standby condition because of program redirection by DOE, calling for the postponement of scale-up and life-testing work,

The test facility design consists of three major subystems: the individual test stands, the test control subsystem, and the data acquisition/ management subsystem. The physical layout of the facility, shown in figure 20, consists of a test area and an adjacent control room.

The individual test stands contain the pumps, flow controllers, sensors, power supplies, load-profile controllers, power conditioning equipment, and tankage necessary to support a given test. The partially completed prototype test stand is shown in figure 21. The test control subsystem consists of the logic circuits and switching capabilities necessary to sequence normal cell startup and shutdown procedures, to respond to unprogrammed operation perturbations, and to execute emergency shutdown steps. The data acquisition/management subsystem configuration includes a minicomputer, microcomputer, data collector, multiplexer, typewriter, cathode-ray tube, and associated keyboards. The minicomputer controls the flow of data to data storage for subsequent analysis on the Lewis central computer.. It also converts data to engineering units for display in the control room, executes required real-time celculations, does continuous limit-cheoks on the test data, and initiates emergency shutdown in case of test failure. The microcomputer serves as the interface between the minicomputer and the test facility. It controls the low of data in both directions and generates hard-copy and/or CRT displays in the control room. Final data reduction and output are accomplished after dats transfer from the data storage system to the Lewis central computing facility.

All equipment operated satisfactorily during the shakedown tests. 


\section{3}

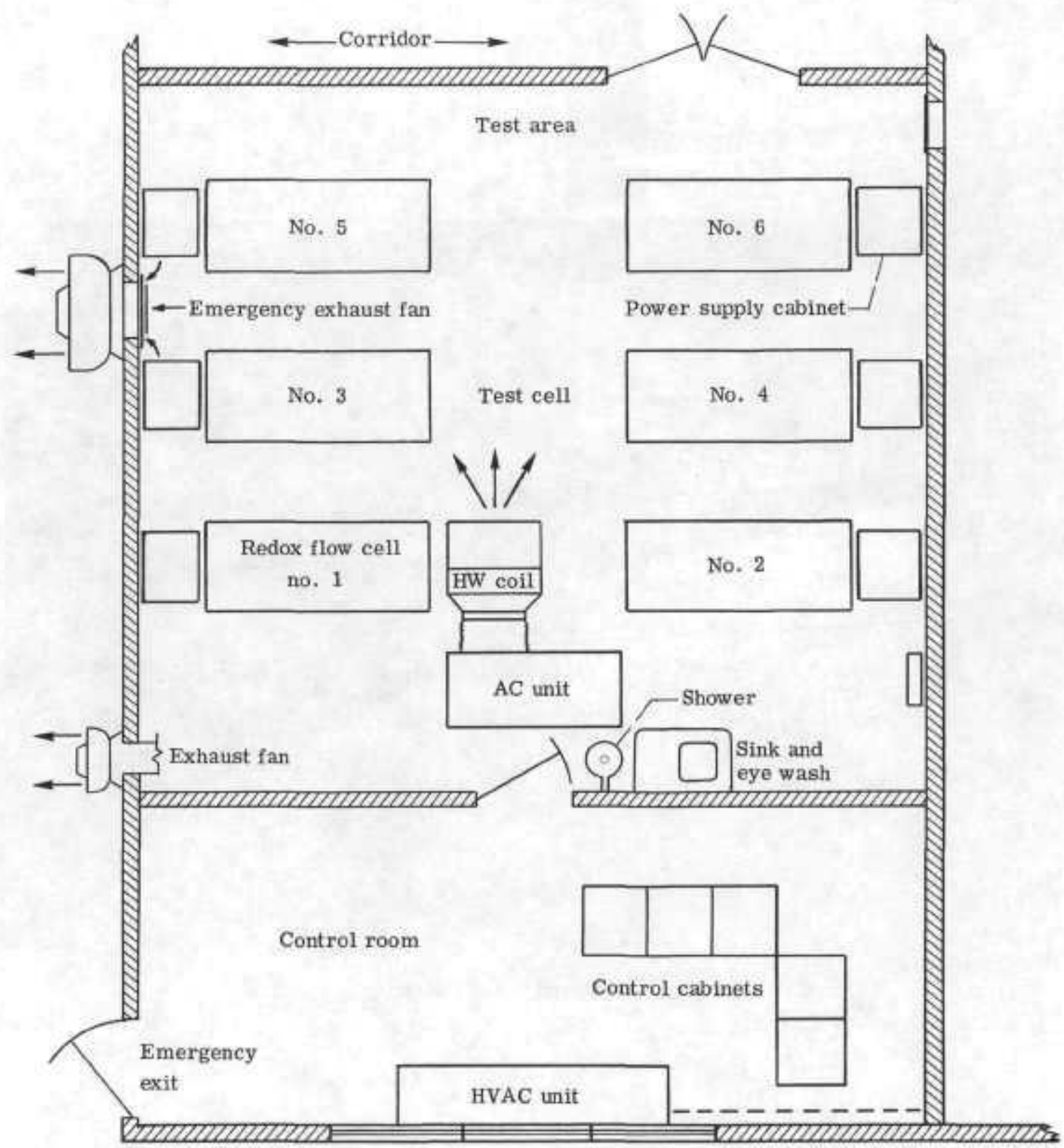

Figure 20. - Floor plan for redox cell/stack test facility. 


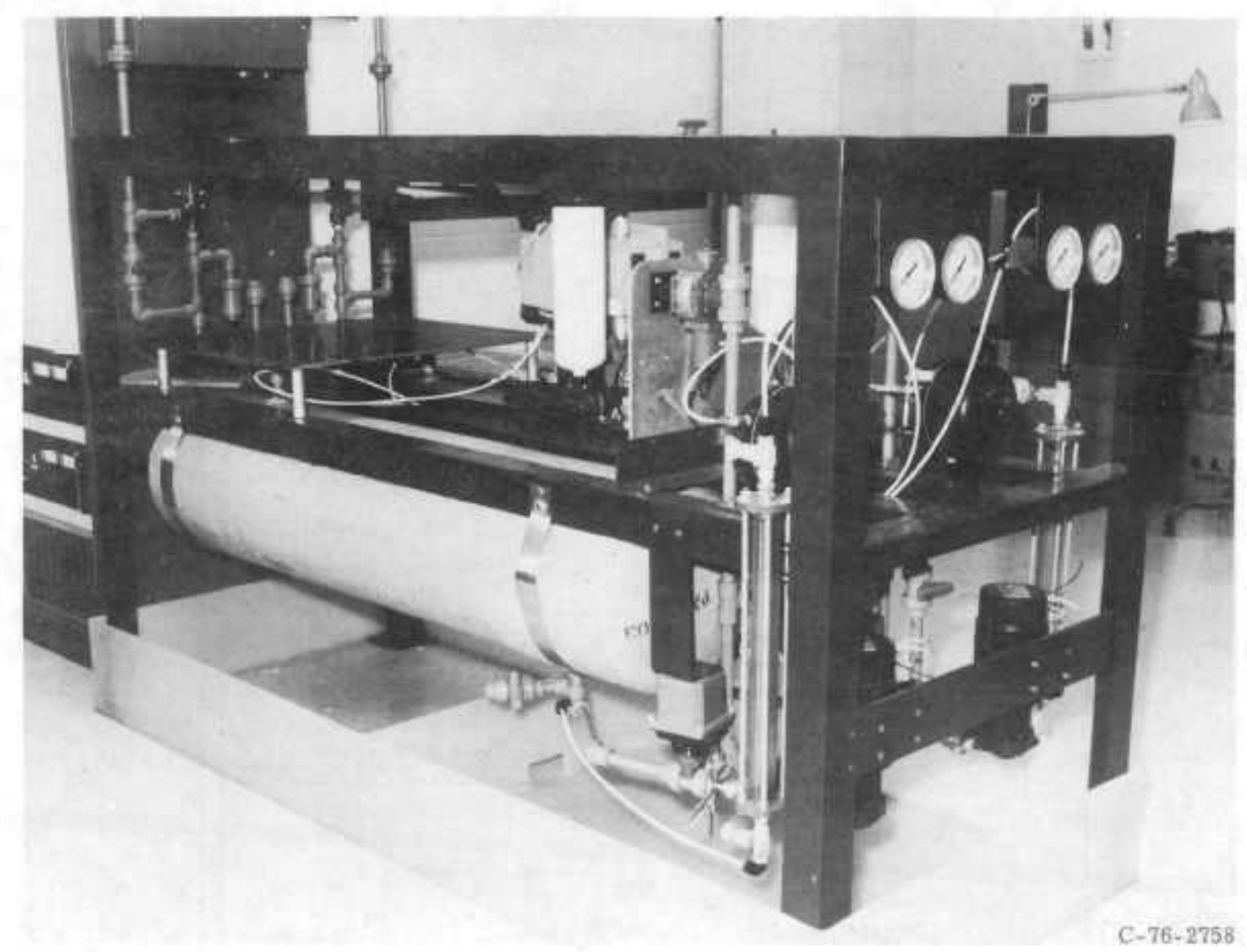

Figure 21. - Partially-completed redox cell/stack test stand, 


\section{REFERENCES}

1. An Assessment of Energy Storage Systems Suitable for Use by Electric Utilities, Final rep. Vol. I. Publtc Service Electric and Gas Co, , 1976. (See also Electric Power Res. Inst., EM-264-Vol, 2.)

2. Reid, Margaret A.; and Gahn, Randall F.: Factors Affecting the OpenCircuit Voltage and Electrode Kinetics of Some Iron/Titanium Redox FIow Cells. ERDA/NASA-1022/77/10, NASA TM X-73669, 1977.

3. Giner, J,; Swette, L.; and Cahill, K.: Screening of Redox Couples and Electrode Materials. (Giner, Inc.; NASA Contract NAS3-19760.) NASA CR-134705, 1976.

4. Miller, Riley O.: Electrochemical Behavior of 0.2 to 3 Molar Ferrous Chloride-Ferric Chloride Mixtures on Edge-On Pyrolytic Graphite Rotated Disk Electrodes. ERDA/NASA-5022/77/2, NASA TM-73716, 1977.

5. Prokopius, Paul R. : Model for Calculating Electrolytic Shunt Path Losses in Large Electrochemical Energy Conversion Systems. NASA TM X-3359, 1976.

6. O' Donnell, Patricia M.; Gahn, Randall F.; and Pfeiffer, Willam: Redox Flow System for Solar Photovoltaic Energy Storage. NASA TM X-73562, 1976.

7. Warshay, Marvin; and Wright, Lyle O.: Cost and Size Estimates for an Electrochemical Bulk Energy Storage Concept. NASA TM X-71805, 1976.

\section{BIBLIOGRAPHY}

Alexander, Samuel S.; Geffroy, Richard R.; and Hodgdon, Russell B.: Anion Selective Membrane. (Final Report, Ionics, Inc.; NASA Contract NAS328897.) NASA CR-134931, 1975.

Clprios, G.; Erskine, W., Jr.; and Grimes, P. G. : Redox Bulk Energy Storage System Study. (Exkxon/GRU, 1 BH, 77-V, 1 and Exxon/GRU, 2 BH. 77-V, 2, Exxon Research and Engiseering Co.; NASA Contract NAS3135206, Vols. 1 \& 2; 1977.

Warshay, Marvin; and Wright, Lyle $O_{.}$: Cost and Size Estimates for a Redox Bulk Energy Storage Concept. J. Electrochem. Soc., vol, 124, no. 2, Feb. 1977, pp. 173-177. 
